\title{
Nanoencapsulation of thyme essential oil: a new avenue to enhance its protective role against oxidative stress and cytotoxicity of zinc oxide nanoparticles in rats
}

Marwa E. Hassan

Research Institute of Medical Entomology

Rasha R. Hassan

Research Institute of Medical Entomology

Kawther A. Diab

National Research Center

Aziza A. El-Nekeety

National Research Center

Nabila S. Hassan

National Research Center

Mosaad Attia Abdel-Wahhab ( $\square$ mosaad_abdelwahhab@yahoo.com )

National Research Center https://orcid.org/0000-0002-7174-3341

\section{Research Article}

Keywords: Zinc oxide nanoparticles, encapsulated thyme essential oil, oxidative stress, cytotoxicity, nanotechnology, antioxidant

Posted Date: February 17th, 2021

DOI: https://doi.org/10.21203/rs.3.rs-157175/v1

License: (c) (i) This work is licensed under a Creative Commons Attribution 4.0 International License. Read Full License 


\section{Abstract}

This study aimed to evaluate the potential protective role of encapsulated thyme oil (ETO) against zinc oxide nanoparticles (ZnO-NPs). ETO was prepared using a mixture of whey protein isolate, maltodextrin, and gum Arabic, and ZnO-NPs were synthesized using parsley extract. Six groups of male SpragueDawley rats were treated orally for 21 days included the control group, ZnO-NPs-treated group $(25 \mathrm{mg} / \mathrm{kg}$ b.w), ETO-treated groups at low or high dose $(50,100 \mathrm{mg} / \mathrm{kg} \mathrm{b.w})$ and the groups received ZnO-NPs plus ETO at the two doses. Blood and tissue samples were collected for different assays. The results showed that carvarcol and thymol were the major components in ETO among 13 compounds isolated by GC-MS. ZnO-NPs were spherical and ETOs were round in shape with an average size of 38 and $311.8 \mathrm{~nm}$, respectively. Administration of ZnO-NPs induced oxidative stress, DNA damage, biochemical, ctyogentical, and histological changes in rats. ETO at the tested doses alleviated these disturbances and showed protective effects against the hazards of ZnO-NPs. It could be concluded that encapsulation of thyme oil using whey protein isolate, maltodextrin and gum Arabic improved ETO properties, probably possess synergistic effects, and can be used as a promising tool in pharmaceutical and food applications.

\section{Introduction}

In recent years, nanotechnology has been utilized in food industries as a tool to produce healthier, safer, and taste better food resulting in the development of a novel category of food named nanofood (Wang et al., 2014a). It is used to improve antimicrobial packaging through the incorporation of some active components that can deliver functional attributes to traditional active packaging (Müller and Schmid, 2019). However, the interactions of the biological systems with nanoparticles have several unpredictable outcomes, hence, the understanding of their toxicity is very essential to protect the human body from their hazardous effects (John et al., 2010; Rasmussen et al; 2010; Sharma et al., 2011). Consequently, in the year 2011, the European Parliament called for additional checks of sufficient safety assessment of the nanofood and requested that all nanofood should be labeled (Wang et al., 2014a). Unfortunately, most of the markets unintentionally or intentionally did not follow these new rules, and till now no specific labels to indicate if the food contains nanomaterials.

ZnO-NPs are used excessively in biomedical applications such as a tool for the imaging of biological systems, cosmetics, and anticancer drugs. Moreover, $\mathrm{Zn}$ is used as a food supplement particularly for children (Pourmirzaiee et al., 2018; Prasad, 2008) and currently during COVID-19 pandemic (Wessels et al., 2020) besides the wide use of ZnO-NPs for longer preservations and extend shelf life of several foods (Wu et al., 2010; Espitia et al., 2012). Despite these beneficial effects of ZnO-NPs, several studies reported that ZnO-NPs produce cytotoxicity in different cell types such as osteoblast cancer cells, kidney cells, hepatocytes, human bronchial epithelial cells, and alveolar adenocarcinoma cells and the toxicity of such nanoparticles may be correlated to the dosage and the size of nanoparticles (Singh, 2019; Wang et al., 2018). Exposure to ZnO-NPs led to cytotoxicity in a time and dose-dependent as a consequence of the oxidative stress, the peroxidation of lipids, the damage of carbohydrates, proteins, cell membrane, and 
DNA (Almansour et al., 2017; Fadoju et al., 2019; Yang et al., 2010). Additionally, because of the high solubility, ZnO-NPs can exist at high concentrations to produce oxidative stress, cytotoxicity, and mitochondrial dysfunction (Wang et al., 2019; Yan et al., 2020)

Thyme (Thymus vulgaris) is an herb widely used as species in human food and has received huge concern because of its beneficial additives in nutrition (Hesabi Nameghi et al., 2019). It has a beneficial role on the health and improves the appetite, the secretion of the endogenous enzyme, activates the immune responses along with its role as an antioxidant, anthelminthic and antiviral properties (El-Nekeety et al., 2011; Toujani et al. 2018). Whereas, some characteristics of the bioactive compounds in the essential oil of thyme especially the high activity, hydrophobia, reactivity, sensitivity to peroxidation, and volatility caused limitations in its use in some foods (Hossain et al, 2019). Consequently, its efficiency and sensory quality probably decreased due to these undesirable reactions resulting in the decrease of palatability if used in high amounts (Lee et al., 2004). The use of encapsulation technique is an attractive tool to protect these active components in the essential oils and also to improve their delivery and controlled release via the entrapment in the core of the nano-capsule structure of membrane wall and/or the adsorption onto the carrier (Abdel-Wahhab et al., 2018). This study was conducted to use whey protein isolate -maltodextrin gum Arabic for the synthesis of encapsulated thyme essential oil and to evaluate their efficiency to counteract the oxidative stress and cytogenetic toxicity of ZnO-NPs in rats.

\section{Materials And Methods}

\section{Chemicals and Kits}

Zinc acetate dehydrates, Maltodextrin (MD), and whey protein isolate (WPI) were purchased from Sigma Aldrich (St. Louis, USA); however, gum Arabic (GA) was provided by San-Ei Gen F.F.I. Inc. (Osaka, Japan). Kits for transaminase (ALT and AST), cholesterol (Cho), triglycerides (TriG), high-density lipoprotein $(H D L)$, low-density lipoprotein (LDL), creatinine, urea, albumin (Alb), and total protein (TP) were obtained from FAR Diagnostics Co. (Via Fermi, Italy). Kits for catalase (CAT), nitric oxide (NO), superoxide dismutase (SOD), and total antioxidants capacity (TAC) were obtained from Eagle diagnostics (Dallas, TX, USA). Malondialdehyde (MDA) was obtained from Oxis Research TM Co. (USA). ELISA kit for alphafetoprotein (AFP) was purchased from Biochem Immuno Systems Co. (Montreal, Canada). Tumor necrosis factor-alpha (TNF-a) kit was purchased from Orgenium (Helsinki, Finland). A kit for measuring carcinoembryonic antigen (CEA) was obtained from Biodiagnostic (Giza, Egypt).

\section{Biosynthesis of ZnO-NPs using parsley extract}

The leaves and roots of parsley were washed by deionized water then $50 \mathrm{~g}$ were submersion in $50 \mathrm{ml}$ water and heated at $70-80^{\circ} \mathrm{C}$ in a water bath. The extract was filtered and the volume was adjusted to $100 \mathrm{ml}$ by washing the vegetal residue with ultrapure water (Stan et al., 2015). For the green biosynthesis ZnO-NPs, $50 \mathrm{ml}$ of parsley aqueous extract was heated at $85-90^{\circ} \mathrm{C}$, followed by the addition of $5 \mathrm{~g}$ zinc acetate dehydrates at $90^{\circ} \mathrm{C}$ under continual stirring for $3 \mathrm{~h}$. The supernatant was filtrated and kept for 72 
$\mathrm{h}$ at room temperature then heated for $24 \mathrm{~h}$ at $90^{\circ} \mathrm{C}$ to obtain ZnO-NPs (Hajiashrafi and Motakef-Kazemi, 2018).

\section{Thyme essential oil (TEO) extraction}

The thyme plant materials $(100.0 \mathrm{~g})$ were placed in 1 liter of water in a round-bottomed flask which connected with Clevenger-type apparatus and the hydro-distillation was performed for $4 \mathrm{~h}$ by boiling of water. The resulted essential oil was dehydrated using sodium sulfate anhydrous and stored at $4{ }^{\circ} \mathrm{C}$ until used.

\section{GC-MS analysis of TEO}

GC-MS analysis was conducted using Hewlett-Packard model 5890 with a flame ionization detector (FID) and DB-5 fused silica capillary column $(60 \mathrm{mx} 0.32 \mathrm{~mm})$. The temperature of the oven was maintained initially at $50^{\circ} \mathrm{C}$ for $5 \mathrm{~min}$ and then programmed from 50 to $250^{\circ} \mathrm{C}$ at a rate of $4{ }^{\circ} \mathrm{C} / \mathrm{min}$. The carrier gas was helium at a flow rate of $1.1 \mathrm{ml} / \mathrm{min}$. The temperatures of the detector and injector were 250 and 220 ${ }^{\circ} \mathrm{C}$, respectively, and the retention indices (Kovats index) of the separated volatile components were calculated using hydrocarbons as references (C7-C20, Aldrich Co.) as shown by Adams (2007).

\section{Preparation of emulation solution of encapsulated thyme oil (ETO)}

MD, GA, and WPI were dissolved in distilled water with stirring. Solutions were kept overnight at room temperature before emulsification. Tween 80 was added to the polymer mixture as an emulsifier. Then, essential oils were progressively added to the polymer solution with homogenization at $20000 \mathrm{rpm}$ for 10 min to form an emulsion. The polymer concentration was $20 \%$, and the amount of essential oil used was $10 \%$ of the mass of the polymer concentration (Tomazelli Júnior et al., 2018). The emulsion solution was encapsulated by spray drying using a spray drier (B-290, Buchi) equipped with a pressure air atomizing nozzle at $2.5 \mathrm{bar}$, inlet temperature of $160 \pm 5^{\circ} \mathrm{C}$, and outlet air temperature of $85 \pm 5^{\circ} \mathrm{C}$. The dried encapsulated oil powder was collected and stored in the refrigerator at $4^{\circ} \mathrm{C}$ until used.

\section{Characterization of ZnO-NPs and ETO}

Scanning electron micrographs (SEM) were recorded on JEOL JAX-840A and JEOL JEM- 1230 electron micro-analyzers, respectively. The ZnO-NPs samples were scattered in ethanol and then treated ultrasonically to disperse the individual particle over the gold grids. However, for ETO, the droplets were placed onto a carbon-coated copper grid to form a thin liquid film and were negatively stained by one drop of uranyl acetate. The excess of staining was removed using filter paper then the film was air-dried before the observation. The Orius 1000 CCD camera was used for image acquisition (GATAN, Warrendale, PA, USA). For measuring zeta potential, the sample of ZnO-NPs or ETO was sonicated for 30-60 min just before assessment. The average diameter, the size distribution, and zeta potential of ZnO-NPs and ETO were measured using a particle size analyzer (Nano-ZS, Malvern Instruments Ltd., UK).

\section{Experimental animals}


Sexually mature male Sprague-Dawley rats (150-160 g; 3 months old) were purchased from AHC, National Research Center (NRC), Dokki, Cairo, Egypt. The animals were fed standard laboratory diet (Meladco Feed Co., Aubor City, Cairo, Egypt) and housed in filter top polycarbonate cages in a room free from any source of chemical contamination, artificially illuminated ( $12 \mathrm{~h}$ dark/light cycle) and thermally controlled $\left(25 \pm 1^{\circ} \mathrm{C}\right)$ at the Animal House Lab, NRC. All animals were received humane care in compliance with the guidelines of the Animal Care and Use Committee of NRC, Egypt, and the National Institute of Health (NIH publication 86-23 revised 1985).

\section{Experimental design}

Six groups of animals (10 rats/group) were preserved on their specific diet and treated orally for three weeks as follows: group1; control animals, group 2; rats received an aqueous solution of ZnO-NPs (25 $\mathrm{mg} / \mathrm{kg}$ b.w), groups 3 and 4; rats received low ( $50 \mathrm{mg} / \mathrm{kg} \mathrm{b.w)} \mathrm{or} \mathrm{high} \mathrm{(} 100 \mathrm{mg} / \mathrm{kg} \mathrm{b.w)} \mathrm{dose} \mathrm{of} \mathrm{an}$ aqueous solution of ETO and groups 5 and 6; rats treated with a low or high dose of ETO [ETO(LD) and ETO(HD)] plus ZnO- NPs. At the end of the experimental period (i.e. day 21), all animals were weighed after being fasted for $12 \mathrm{hr}$, then blood samples were collected via the retro-orbital venous plexus under diethyl ether anesthesia. Sera were separated using cooling centrifugation and stored at $-20{ }^{\circ} \mathrm{C}$ until analysis. After the collection of blood samples, animals were sacrificed and samples of the spleen, former bone marrow, livers, and kidneys of each animal were dissected. A sample of liver and kidney from each animal was weighed and homogenized in phosphate buffer $(\mathrm{pH} 7.4)$ for the determination of MAD, NO, CAT, SOD, and TAC (Lin et al., 1998). Other samples of the liver and kidney from each animal were fixed in $10 \%$ neutral formalin and paraffin-embedded. Sections ( $5 \mu \mathrm{m}$ thickness) were stained with hematoxylin and eosin (H \& E) for the histological examination (Drury and Wallington 1980).

\section{Cytogenetic analysis}

\section{Single-cell electrophoresis (comet) assay}

Alkaline comet assay was performed on bone marrow cells and spleen as described previously (Diab et al. 2018). The slides were stained with ethidium bromide and visualized at $400 \times$ magnification under an epifluorescent microscope equipped with a digital camera and green excitation filter (510-560 nm) and barrier filter $(590 \mathrm{~nm})$. One-hundred cells were analyzed per animal using comet score software (TriTek Corp, version 1.5., Sumerduck, VA22742, VA). The percentage of DNA in the comet tail (tail intensity) is considered to be the most reliable parameter to quantify DNA damage. The cells with $>80 \%$ DNA in the tail region were classified as hedgehogs and excluded from software analysis.

\section{Micronucleus Assay}

The MN assay was carried out in bone marrow cells according to Diab et al. (2018). The bone marrow slides were stained with May-Grünwald and Giemsa staining to discriminate between polychromatic erythrocytes (PCEs) and normochromatic erythrocytes (NCEs). Two-thousand PCEs were analyzed per animal under light microscopy at 1000x magnification for counting the frequency of micronucleated 
PCEs (MNPCEs). Five-hundred total erythrocytes (PCEs+ NCEs) were examined per animal, and the ratio of PCE/total erythrocytes was calculated to determine erythroblast proliferation rate or erythroblast cytotoxicity

\section{Morphological apoptosis assay}

The dual-fluorescent acridine orange and ethidium bromide (AO/EB) assay was performed for the observation of morphological apoptosis including chromosome condensation on bone marrow cells as described previously (Diab et al. 2018). Briefly, the slides were stained with a dual-fluorescent mixture of AO $(5 \mathrm{mg} / \mathrm{ml})$ and EB $(5 \mathrm{mg} / \mathrm{ml})$ for 2-5 min. In this assay, AO enters viable and nonviable cells and emits green or red fluorescence when binding to DNA or RNA, respectively. EB enters nonviable cells and emits orange or red fluorescence when binding to DNA or RNA, respectively. Hence, normal and apoptotic nuclei emit bright orange fluorescence in non-viability case. Five-hundred cells were examined per animal under an epifluorescent microscope at 400xmagnification with a blue excitation filter $(480 \mathrm{~nm})$ and a yellow emission barrier filter $(515-530 \mathrm{~nm})$. The apoptotic index was calculated according to the following formula: [number of apoptotic cells /total cell count] $\times 100$.

\section{Statistical analysis}

The data were analyzed using computerized software SPSS (Statistical Package of Social Science, version 20, Armonk, New York: IBM Corp). One-way analysis of variance (ANOVA) followed by Duncan's multiple comparisons test was used to determine the difference among the experimental groups. The level of statistical significance was set at $\mathrm{P}<0.05$.

\section{Results}

The GC-MS analysis of the ETO revealed the identification of 13 bioactive compounds (Table 1) belongs to 5 classes including phenols, terpene, sesquiterpene, oxides, and oxygenated terpene. The majority of these compounds were phenols (carvarcol and thymol) followed by terpene ( $\alpha$ and $\beta$-phellandrene, linalool, myrcene, $\alpha, \beta$-pinene, $\beta$-sabinene, and Tricyclene). Sesquiterpene (humuline), oxides (1, 8-cineole), and oxygenated terpene (a-thyjone) were found in a lesser concentration.

The results showed that the addition of $50 \mathrm{ml}$ of heated parsley extract to $5 \mathrm{~g}$ zinc acetate dehydrates and stirring for $3 \mathrm{~h}$ then the filtration of the supernatant after $72 \mathrm{~h}$ resulted in the synthesis of ZnO-NPs. The TEM image revealed that the particles are nearly spherical (Fig1A) with an average particle size of $38 \mathrm{~nm}$ (Fig. 1B) and a zeta potential of $+28.58 \mathrm{mV}$ (Fig 1C). The TEM image of ETO showed a rounded shape (Fig. 1D) with an average diameter of $311.8 \pm 27 \mathrm{~nm}$ (Fig. 1E) and a zeta potential of $-21.63 \mathrm{mV}$ (Fig. 1F).

The in vivo results showed a significant decrease in body weight in the animals treated with ZnO-NPs compared to the control group (Fig.2). Animals treated with ETO at the low or the high doses were comparable to the control group. However, the combined treatment with ETO plus ZnO-NPs induced a significant improvement in body weight in a dose-dependent and the high dose could normalize the body 
weight. The results also revealed that the administration of ZnO-NPs induced a significant increase in AST, ALT, uric acid, urea, and creatinine; however, TP and Alb showed a significant decrease (Table 2). Animals that received ETO at the low or high dose were approximately similar to the untreated control group. The combined treatment with ETO plus ZnO-NPs improved significantly all the tested parameters and ETO at the high dose succeeded to normalize most of these parameters.

The effect of ZnO-NPs treatment alone or plus ETO on serum lipid profile (Table 3) indicated that ZnONPs administration induced a significant increase in cholesterol, triglycerides, and LDL accompanied by a significant decrease in HDL. Animals who received ETO alone showed a significant decrease in cholesterol, triglycerides, and increased HDL but did not significantly affect LDL. Co-administration of ZnO-NPs and ETO induced a significant improvement in lipid profile parameters toward the control levels in a dose-dependent and most of these parameters were similar to the untreated control animals. The antioxidant parameters (TAC, CAT, and SOD) in the liver and kidney showed a significant decrease in the rats that received ZnO-NPs compared to the control rats (Table 4). These antioxidant parameters showed an insignificant increase in the groups treated with TEO in a dose-dependent. However, the combined treatment with ETO plus ZnO-NPs could improve these antioxidant parameters and the high dose was more efficacious than the low dose.

The effect of different treatments on oxidative markers MDA as the main product of lipid peroxidation and NO (Table 5) revealed that ZnO-NPs administration significantly increased both parameters in the liver and kidney. No significant effect was observed in NO in both organs in animals that received ETO alone at the two doses. However, ETO decreased MDA in both organs in a dose-dependent. The combined treatment with ETO plus ZnO-NPs induced a significant improvement in hepatic and renal MDA levels in a dose-dependent manner. In addition, ZnO-NPs administration increased AFP, TNF-a, and CEA (Table 6); however, animals that received ETO at the two doses did not show any significant changes in AFP and TNF-a but the high dose decreased CEA significantly. Treatment with ZnO-NPs plus ETO (LD) or ETO (HD) could normalize AFP and TNF- $a$ and decreased CEA compared to the control group (Table 6).

\section{Comet assay}

The data presented in Fig. (3a, b) showed the effect of ZnO-NPs and ETO on the level of DNA breakages in bone marrow cells and spleen using the comet assay. In this assay, intact cells reflect high-molecularweight genomic DNA and appear nearly rounded (comet head) or with a very short tail (Fig 4a). The cells with broken DNA embedded in agarose gel migrated toward the anode leaving different patterns of the comet-like electrophoretic trail. This trail is characterized by the head (intact DNA) and tail which reflects the amount of DNA breakage (Figs. 4b, c, d). Administration of ZnO-NPs increased the percentage of DNA breakage in the comet tail in bone marrow $(9.41 \%$ vs $5.41 \%$ for the control) and spleen $(16.39 \%$ vs $5.48 \%$ for the control). By contrast, ETO at the tested doses did not induce any significant increase in the percentage of DNA in the comet tail in bone marrow and spleen compared to their control values. Interestingly, supplementation with ETO significantly decreased the percentage of tail DNA damage in bone marrow and spleen compared to the ZnO-NPs alone-treated group. There is no significant decrease 
$(p>0.05)$ in the percentage of DNA breakage between the groups treated with the low or high dose of ETO plus ZnO-NPs. The reduction in DNA breakage reached 8.10 and $7.66 \%$ in bone marrow, and 12.66 and $11.79 \%$ in the spleen after co-treatment with the two doses of ETO, respectively. Noteworthy, the incidence of hedgehog comet was noticed in bone marrow and spleen (Fig. 4d)

\section{Micronucleus Assay}

As shown in Table (7), the administration of ZnO-NPs caused a 6-fold increase in MNPCE percentage $(1.09 \%$ vs $0.18 \%$ for the control, $p<0.05)$ in bone marrow cells. However, no significant differences were observed in the percentage of MNPCE after treatment with ETO at the two doses $(0.20 \%$ and $0.24 \%$, respectively) compared to the control group. Co-treatment with ZnO-NPs and ETO at both doses significantly reduced the percentage of MNPCE $(0.33 \%$ and $0.46 \%$, respectively, $p<0.05)$ compared to the ZnO-NPs alone-treated group. As depicted in Fig. (5), the observed micronuclei were varied in size (small or large) and shape (dot or round). Surprisingly, no significant difference $(p<0.05)$ in the ratio of PCE/ total erythrocytes was observed in all treated animals compared to the untreated control animals.

\section{Morphological apoptosis assay}

As depicted in Fig (6A), intact cells were surrounded by regular cell membranes without chromatin condensation. The early apoptotic cells were still bounded with irregular cell membranes containing patches of condensed chromatin distributed in the nuclear periphery. The late apoptotic cells appeared as a grape-like cluster containing protrusion of chromatin distributed in a few spherical apoptotic bodies (Fig. 6B, C). Our findings showed that ETO did not dramatically produce any increase in the apoptotic rate compared to the untreated control group. However, ZnO-NPs treatment exhibited a more pronounced frequency of early apoptotic cells inducing a significant increase in the apoptotic rate $(11.96 \%$ vs $6.44 \%$ for the control, $\mathrm{p}<0.05)$. Supplementation with the two doses of ETO significantly suppressed ZnO-NPsinduced apoptotic rate from 11.965 to 8.88 and $7.60 \%$, respectively (Fig 6D).

The examination of liver sections revealed the control liver showed normal architecture with a classic hepatic lobule-containing central vein and radiating cords of hepatocytes with blood sinusoids in between, polyhedral hepatocytes with large, rounded vesicular nuclei. The blood sinusoids are present in between the cords of hepatocytes and are lined by flattened endothelial cells and Kupffer cells (Fig 7A). The liver sections of animals that received ZnO-NPs showed hepatocytes vacuolar degeneration and pyknotic nuclei (Fig. 7B). The liver of rats treated with ETO(LD) showed normal hepatocytes around the central vein (Fig. 7C). Moreover, the liver of rats treated with ETO(HD) showed nearly normal hepatocytes around the normal central vein (Fig. 7D). The liver sections of the rats treated with ZnO-NPs plus ETO(LD) showed no remarkable changes in hepatocytes and their blood vessel architecture (Fig. 7E). Furthermore, the liver of rats that received ZnO-NPs plus ETO(HD) showed marked improvement in the hepatocytes histological architecture and a marked decrease in inflammatory cells (Fig. 7F).

The examination of kidney sections of the control rats showed normal histology of glomeruli and renal proximal and distal convoluted tubules (Fig. 8A). However, the kidney of the rats received ZnO-NPs 
showed swelling of the tubular lining epithelium with variable degrees of granular and single-cell necrosis and nuclear pyknosis among the tubular epithelium, diminished and distorted glomeruli, and atrophy of the glomerular tufts with mesangial necrosis (Fig. 8B). The kidney of rats treated with ETO(LD) or ETO(HD) showed nearly normal renal tubules and glomeruli (Fig. $8 \mathrm{C}, \mathrm{D}$ ). The kidney sections of the rats treated with ZnO-NPs plus ETO (LD) showed marked improvement in renal tubules and glomeruli cellularity (Fig. 8E). The kidney sections of the rats treated with ZnO-NPs plus ETO (HD) showed foci of epithelial cell necrosis (Fig. 8F).

\section{Discussion}

The results of the GC-MS analysis of the thyme essential oil revealed the occurrence of 13 compounds. Phenolic compounds (carvarcol and thymol) were the major compounds followed by Terpene ( $\alpha$ and $\beta$ phellandrene, linalool, myrcene, $\alpha, \beta$-pinene, $\beta$-sabinene, and Tricyclene) then sesquiterpene (Humuline). Other constitutes such as oxides and oxygenated terpenes were found in a minor concentration. Previous reports indicated that the majority of compounds in thyme oil are carvarcol and thymol (Rota et al., 2007). In this concern, Ahmad et al (2014) isolated 22 compounds and the majority were thymol and pcymene; however, Borugă et al. (2014) isolated 15 compounds and the majority were p-cymene, $\gamma^{-}$ terpinene and thymol. Razzaghi-Abyaneh et al. (2009) also isolated 7 compounds from thyme essential oil and these authors suggested that the variation in the chemical composition may be due to the variety of the plane and the geographical regions

Recently, there is a growing interest in the synthesizing of ZnO-NPs through biological methods. The development of such a new approach is mainly linked to the safety, eco-friendly and cost-effective beside the reduction of high energy or the decrease of the toxic chemicals used in the biological syntheses (Khalid et al., 2017; Krol et al., 2017). In the current study, the addition of zinc acetate to the parsley extract then submitted to thermal treatment led to the biosynthesis of ZnO-NPs nearly spherical in shape, the particle size of $38 \mathrm{~nm}$ and zeta potential of $+28.58 \mathrm{mV}$. Similar biosynthesis processes were carried out using different plant extracts (Krol et al., 2017). These authors and others reported that the particle size and morphology of the produced $\mathrm{ZnO}$-NPs were affected by $\mathrm{pH}$ variations, the concentration of zinc, the temperature, and the reaction time (Bala et al., 2015). Additionally, MD, GA, and WPI were successfully used in the encapsulation of the oil in a ratio of 2: 1 (polymer: oil) and the encapsulated oil showed a rounded shape with an average diameter of $311.8 \pm 27 \mathrm{~nm}$ and zeta potential of $-21.63 \mathrm{mV}$. The encapsulation of thyme oil was carried out using different polymers such as chitosan to protect the oil from oxidation and to improve its characteristics (Mohammed et al., 2020)

In the current study, we defined various effects of ZnO-NPs in rats. The majority of these effects were the significant changes in body weight and the indices of blood chemistry, the alteration in antioxidant enzyme activity, the cytokines, cytogenetic, and the histological structure of liver and kidney. Although the FDA recognized that micron-sized zinc oxide $(\mathrm{ZnO})$ as a safe material, the safety of ZnO-NPs for animal consumption did not determine yet. The current results showed that administration of ZnO-NPs increased AST, ALT, uric acid, urea, and creatinine and decreased TP and Alb. The AST and ALT are the potent 
biochemical indices for the detection of the damage of liver tissue (Srivastav et al., 2016). The increase in these enzymes reported herein suggested that ZnO-NPs altered the permeability of the hepatocellular membrane. In this concern, Singh et al. (2001) reported that the covalent binding of a drug to the intracellular proteins induces a reduction in adenosine triphosphate (ATP) level leading to the actin disruption and the rupture of the cell membrane. Moreover, it was reported that in the oral administration, $\mathrm{ZnO}$ may be dissolved in the stomach because of the acidic condition resulting in the formation of $\mathrm{Zn}^{+2}$ leading to cause significant toxicity (Srivastav et al., 2016). Similar observations were reported by Wang et al. (2006) in mice treated with nano- and micro-scale zinc powder. Moreover, urea, uric acid, and creatinine are considered the best indicators for renal function and they increase dramatically during kidney dysfunction. Our results indicated that these kidney indices increased in animals treated with ZnONPs suggesting that these particles affect the filtration rate of the glomerular and the ability of the kidney to induce blood filtration (Llobet et al., 1988). Moreover, the decreased level of TP and Alb in the group treated with ZnO-NPs suggested liver necrosis and/or kidney dysfunction (Abdel-Wahhab et al., 2007). Additionally, the decreased level of albumin may also be explained by its consumption for the defense against the oxidative stress of ZnO-NPs (Diab et al., 2015). Animals that received ZnO-NPs alone showed a significant increase in cholesterol, triglycerides, LDL, and a significant decrease in HDL suggesting a status of dyslipidemia. Dyslipidemia is considered a high-risk factor for coronary heart diseases (Allouche et al., 2011). Consequently, the current results indicated that ZnO-NPs are probably responsible for the disturbances in the lipid profile and the atherosclerosis risk (Moatamed et al., 2019).

The reduction in TAC, SOD, and CAT in hepatic and kidney of animals received ZnO-NPs and the elevation of MDA and NO indicated a status of oxidative stress and lipids peroxidation in the liver and kidney generated by the exposure to ZnO-NPs. According to Saliani et al. (2016), MDA is the main degradation product of the lipid peroxidation; whereas, $\mathrm{NO}$ is an important free radical which induces severe damage to cells when produced excessively in the tissues or serum (Dillioglugil et al., 2012). A previous study reported that oxidative stress-mediated cytotoxicity and DNA damage induced by ZnO-NPs in human HepG2 cells (Sharma et al., 2011). Moreover, Sha et al (2014) showed that the generation of oxidative stress is the main mechanism of ZnO-NPs toxicity. The current results are in accordance with the previous studies of Moatamed et al. (2019). Taken together, the decreased levels of antioxidants and the increased levels of MDA and NO confirmed that ZnO-NPs enhance the generation of ROS which include superoxide anions, hydrogen peroxide, and hydroxyl radicals, thus cause oxidative damage to the cells and organs (Sharma et al., 2012; Tang et al., 2016). The current results also showed that ZnO-NPs administration increased the serum TNF- $a$, AFP, and CEA suggesting the disturbance of the immune system. Tang et al. (2016) indicated that ZnO-NPs increased the white blood cell counts mainly granulocyte and neutrophil and decreased the lymphocyte count which reflects the inflammatory reaction and the immune dysfunction. Generally, the increased level of MDA, NO, TNF- $a$, AFP, and CEA and the decrease in TAC, SOD, and CAT suggested that the toxicity of ZnO-NPs is mainly via the production of reactive oxygen species (ROS) and inflammation (Tian et al., 2016; Yang et al. 2010). 
The in vivo genotoxicity studies of ZnO-NPs are limited, restricted to mice, and remain controversial. To explore the genotoxicity of ZnO-NPs, the combined comet DNA, and micronucleus assays are recognized by international organizations (Kasamoto et al. 2017). Comet assay is generally measured DNA strand breaks, incomplete excision repair, and cross-linking sites in individual cells (Kang et al. 2013). However, the micronucleus test provides information about the structural or numerical abnormalities induced by clastogenic or aneugenic agents, respectively (Vasquez 2010). The large and small-size micronuclei are represented as a whole chromosome or acentric fragment, respectively, that dropped throughout the anaphase stage of the erythrocyte nucleus, during the degeneration process (Hashimoto et al. 2010).

In the study, ZnO-NPs were positively genotoxicity in bone marrow cells, and spleen using the micronucleus test and comet assay. These results are agreed with earlier in vitro and in vivo studies (Fadoju et al. 2019; Ghosh et al., 2016). Sharma et al. (2012) showed that the oral administration of ZnONPs induced DNA breakage in mouse liver and Ghosh et al. (2016) found that single intraperitoneal exposure to ZnO-NPs induced genotoxicity in both liver (comet assay) and bone marrow (chromosomal aberration and micronuclei). Likewise, Pati et al. (2016) exhibited that single oral inoculation with ZnONPs induced micronuclei in mice blood and bone marrow cells. However, another in vitro study reported that ZnO-NPs induced genotoxicity in human peripheral blood (Shalini et al. 2018), Chinese hamster lung fibroblasts (Reis Ede et al. 2015), Chinese hamster ovary (CHO-K1) cells, and human liver cancer HepG2 cells (Sharma et al. 2011).

It appears that the genotoxicity of ZnO-NPs depends on the following factors: (1) experimental conditions including the dosage, route of administration, treatment period, animal model, sensitivity of the cells, and genetic biomarkers; (2) physiochemical properties including shape, size, surface charged, and rate of agglomeration; (3) disparity in the bio-distribution and accumulation of $\mathrm{Zn}^{+2}$ inside the tissues (Shalini et al. 2018; Singh 2019). Following the oral administration of Zn-NPs (20-120 nm in size), the liver, heart, pancreas, bone, and spleen are the target organs for its accumulation in mice (Wang et al. 2008).

\section{Surprisingly, ZnO-NPs had an insignificant impact on the ratio of PCE/total erythrocyte although it} induced micronuclei formation in the bone marrow erythrocytes. This observation is agreed with Ghosh et al. (2016), who found that ZnO-NPs did not induce any significant reduction in the cytotoxicity of erythroblast in mouse bone marrow cells. Likewise, ZnO-NPs with a small particle size showed lower cytotoxicity and higher genotoxicity in human peripheral blood lymphocytes compared to ZnO-NPs with a large particle size (Shalini et al. 2018).

The dual-fluorescent AO/EB assay is used as an indicator of membrane integrity to assess apoptosis/cytotoxicity (Kasibhatla et al. 2006). In our study, ZnO-NPs elicited cytotoxicity in whole nucleated bone marrow cells, as evidenced by the increase of apoptotic rate. These data implied that ZnO-NPs enter the body, are distributed throughout the body, and elicited cytotoxicity in different animal organs (Li et al. 2012). This outcome agreed with Zarria-Romero et al. (2017), who found that ZnO-NPs $(1-10 \mathrm{mg} / \mathrm{kg}$ ) reduced cell viability in bone marrow cells of mice using MTT assay during $30 \mathrm{~h}$ from intraperitoneal inoculation. Further, the cytotoxic potential of ZnO-NPs has been documented in mouse bone marrow mesenchymal stem cells (Syama et al., 2014), and human blood cells (Shalini et al. 
2018) using MTT assay. Similarly, ZnO-NPs induced cytotoxic, genotoxic, and anticancer activities at low concentrations in human promyelocytic leukemia HL-60 (Soni et al. 2017), cervical (HeLa), and lung (NClH460) cancer cell lines (Esparza-Gonzalez et al. 2016). In the context, ZnO-NPs are selected as chemotherapeutic drugs due to their selective toxicity to preferentially kill cancer cells with minimal toxicity toward normal human cells (Gümüş et al. 2014). It appears that genotoxicity and cytotoxicity of ZnO-NPs with small particle sizes may be attributed to the rapid dissolution of $\mathrm{Zn}^{+2}$ in the aqueous solution (Mudunkotuwa et al. 2012). The release of $\mathrm{Zn}^{+2}$ can be easily disrupted the cell membrane, induced ROS generation, impaired the mitochondria, and induced genotoxicity and cell death (Sharma et al. 2012; Wang et al. 2014).

The histological examination of the hepatic and renal sections in rats received ZnO-NPs showed severe histological changes typical to those reported in the previous studies (Moatamed et al., 2019; Shaban et al., 2019). These findings confirmed the biochemical results reported herein and supported the hypothesis that ZnO-NPs induced severe hepato-nephrotoxicity mainly through the generation of oxidative damage and the immunodeficiency response.

The antioxidant and prophylactic activity of ETO are scarce and focused on its main chemical constituents (thymol and carvacrol), and hepatoprotective activity in rodents (El-Nekeety et al., 2011; Grespan et al., 2014). In recent years, more efforts were focused on the encapsulation of essential oils to reduce their high volatility, toxicity, and decomposition. In this sense, it is necessary to re-evaluate ETO to ensure its safety and prophylactic activity. Animals administrated ETO at the low or the high doses alone were comparable to the control and the combined treatments with ZnO-NPs plus ETO showed potential protection against ZnO-NPs toxicity. Most of the tested parameters showed significant improvement towards the control values and the high dose was more effective. Similar observations were reported by Ündeğer et al. (2009) and El-Nekeety et al. (2011) who suggested that carvacrol and thymol exhibited higher antioxidants in cell-free assay than Trolox. Moreover, thymol decreased ROS production and inhibited hepatotoxicity induced by $\mathrm{CCl}_{4}$ (Alam et al., 1999). The use of encapsulated thyme oil-induced more protection since the encapsulation increased the antioxidant efficiency of the oil (Gonçalves et al., 2017).

Moreover, phenolic thymol and carvarcrol were found to induce the high antioxidative effect of LDL and decrease plasma levels of triglycerides and cholesterol without adverse effects in kidneys or liver (Ebenyi et al., 2012). Additionally, they act on inflammatories by preventing the proinflammatory factors secretion via the decrease of lipopolysaccharide (LPS) (De Andrade et al., 2017). Moreover, carvacrol, the phenolic compounds in the EOs of thyme induced apoptosis in metastatic breast cancer cell line MDA-MB-231 through the permeabilization of mitochondrial membrane, consequently the release of cytochrome $C$, induction of the caspases, and DNA fragmentation (Arunasree, 2010). These compounds also are important free radicals scavengers' natural products and possess antioxidant properties (Ebenyi et al., 2012). Besides, this oil may increase the level of other natural antioxidants in the body, such as GSH, SOD, and CAT, which protect the liver from PAR-induced hepatotoxicity (El-Banna et al., 2013). The hepatoprotective activities of ETO may be through the improvement of hepatocytes function by (i) The 
inhibition of cytochrome P450 activity, (i) the acceleration of parenchyma cells regeneration, (iii) stabilizing the membrane of the hepatocytes, (iv) the enhancement of antioxidant activity and (v) a combination of the all-aforementioned factors (Al-Fartosi et al., 2011).

The genotoxicity results indicated that ETO alone at the two tested doses had no response in rat bone marrow cells and spleen, indicating its safety. In agreement with this view, ETO is classified as moderately toxic and falls into category 4 (>300-2,000 mg/kg b.w) with an LD ${ }_{50}$ cut-off value (1000 $\mathrm{mg} / \mathrm{kg}$ ) in rats (Rojas-Armas et al. 2019). Similarly, oral administration of carvacrol $(81,256$, or 810 $\mathrm{mg} / \mathrm{kg}$ ) did not induce mutagenic activity in rat bone marrow cells using micronucleus and comet assay (Esparza-Gonzalez et al., 2016). Likewise, "In vitro" studies for carvacrol and thymol exhibited no mutagenic effect in Chinese hamster lung fibroblast (V79) cells (Ündeğer et al. 2009), human lymphocytes (Turkez and Aydin 2016), and mouse lymphoma cells (Maisanaba et al. 2015). Noteworthy, the loss of apoptotic activity of ETO in bone marrow cells is in harmony with the absence of its genotoxicity in our study. Indeed, apoptotic or cytotoxic activity is normally associated with extensive DNA fragmentation and is thus considered a secondary outcome of genotoxicity. Recently, thyme oil, carvacrol, and thymol did not exhibit cytotoxic activity (MTT assay) in mouse leukocytes obtained from its peritoneal cavity (Fachini-Queiroz et al., 2012).

Supplementation with ETO has successfully reversed the genotoxic and the apoptotic activity induced by ZnO-NPs, in the spleen and bone marrow. These data implied that ETO interferes with ZnO-NPs and prevent attacking the DNA molecule. Similar studies exhibited the in vitro antimutagenic activity of thyme oil and its chemical constituents (Aydın et al., 2005; Ipek et al., 2003). For example, thymol and carvacrol had effectively genoprotective activity using comet assay in human cancer cells including leukemia K562 (Horvathova et al., 2007), liver HepG2, and colon Caco-2 (Horvathova et al., 2006). Due to a lack of apoptotic/cytotoxic activity of ETO in normal mammalian tissues, ETO is considered more suitable for food and pharmaceutical industries.

In the current study, WPI, MD, and GA were used in the encapsulation of the essential oil as a wall material; hence, we can propose another mechanism for ETO-induced protection. WPI is a well-known antioxidant and hepatoprotective agent (Gad et al. 2011) due to its ability to increase the level of tissue glutathione (Bayrama et al. 2009; Mohammed et al., 2020). It is rich in the amino acids cysteine, alactoglobulin, bovine serum albumin, and $\beta$-lactoglobulin (Morr and $\mathrm{Ha}$ 1993). Cysteine is responsible for the regulation of GSH which responsible for the protection against the damage of cells (Bounous et al. 1989). Additionally, MD is a polysaccharide well known to exhibit antioxidant activity (Wang et al. 2016) and can scavenge several ROS such as 2,2-diphenyl-1-picrylhydrazyl (DPPH), hydroxyl radical, $\mathrm{H}_{2} \mathrm{O}_{2}$, peroxyl radical, ABTS radical, superoxide radical, and alkyl radical and exhibit reducing power properties (Wang et al. 2017; Zhong et al. 2019). The antioxidant effects of polysaccharides can alleviate the risk of several diseases resulted from oxidative stress such as liver injury, neurodegenerative disease, breast cancer, obesity, colitis, and diabetes ( $\mathrm{Li}$ et al. 2017) via three direct mechanisms including the scavenging of ROS, the regulation of the antioxidant system and oxidative stress-mediated signaling pathways. Hence, MD in the wall of ETO probably induces a synergistic protective activity and enhances the 
antioxidant activity of ETO in addition to its role in the scavenging of ROS generated by ZnO-NPs (Zhong et al. 2019). Additionally, the use of GA in the encapsulation process enhanced the protective activity of ETO. GA consists of branched chains of polysaccharides. Polysaccharides are being used to reduce experimental toxicity as it has strong antioxidant properties (Kong et al., 2014). Moreover, GA is well known to improve the antioxidant status of the human body and induced hepatoprotection by modulating the expression of several oxidative stress genes (Ahmed et al., 2015). A previous study also suggested that GA is rich in phenolics which are correlated to its antioxidant than its scavenging power (Edet et al., 2015; Mirghani et al., 2018; Sahu and Saxena, 2013). GA was also reported to decrease superoxide production and MDA and increased TAC and GSH levels in rats (Ali et al., 2010; Al-Yahya et al., 2009). Furthermore, the antioxidant capacity of GA may be attributed to its content of different amino acids (Ali et al., 2020; Khalid et al., 2017) beside it has anti-inflammatory and immune-modulatory actions in mice (Edet et al., 2015; et al., Kamal 2018) via attenuating C-reactive protein and TNFa and increasing the anti-inflammatory cytokine IL10 (Ali et al., 2013; Ushida et al., 2011).

Overall, the protective and antimutagenic activity of ETO is attributed to the antioxidant activity of the phenolic compounds in this oil and also the antioxidant activity of the materials used in the encapsulation process (i.e. WPI, GA, and MD). These compounds can inactivate the mutagens through multiple mechanisms, including (1) suppression of attacking off the mutagens into the DNA molecule; (2) scavenging of free radical produced by mutagens; (3) promoting DNA repair pathway; (4) stimulation of antioxidant defense system; (5) suppression lipid peroxidation (Bhalla et al. 2013; El-Nekeety et al. 2011; Grespan et al. 2014) and (6) the role of WP in the stimulation of a synergistic activity and the enhancement of GSH synthesis (Kent et al. 2003).

\section{Conclusion}

The current study concluded that ZnO-NPs with a particle size of $38 \mathrm{~nm}$ can be synthesized by green chemistry using parsley extract. Administration of ZnO-NPs to rats induced severe toxicity and oxidative stress leading to biochemical changes including liver and kidney indices, the disturbances of lipid profile, oxidative damage, cytotoxicity, immunotoxicity, and histological changes in the liver and kidney.

Encapsulation of thyme essential oil in whey protein enhanced the antioxidant activity of the oil and protect against the oxidative damage of ZnO-NPs. In this study we achieved several goals including (1) the ability to produce ZnO-NPs with particles size of $38 \mathrm{~nm}$ using green chemistry; (2) evaluate the oxidative stress, immunotoxicity, and cytotoxicity of ZnO-NPs in rats; (3) evaluate the protective role of encapsulated thyme essential oil against oxidative stress of ZnO-NPs. These protective properties were due to the s synergistic effects of the bioactive phenolic compounds in the oil as well as the protective role of WPI, MD, and GA used in the encapsulation. Consequently, ETO may be a suitable candidate for food and pharmaceutical applications.

\section{Declarations}

\section{Ethical Approval}


All animals were received humane care in agreement with the guidelines of the Animal Care and Use Committee of the National Research Center, Dokki, Cairo, Egypt and the National Institutes of Health (NIH publication 86-23 revised 1985) under the ethical approval \# 12050305 (Dec 2019).

\section{Consent to participate}

Not applicable

\section{Consent for publication}

Not applicable

\section{Authors Contributions}

This work was carried out in collaboration between all authors. Authors ME Hassan, RR Hassan, KA Diab, AA El-Nekeety and NS Hassan carried out the experimental work, managed the literature searches and shared in writing the first draft of the manuscript. Author MA Abdel-Wahhab wrote the protocol, managed the project, managed the analyses of the study, performed the statistical analysis and wrote the final draft of the manuscript. All authors read and approved the final manuscript.

\section{Funding}

This work was supported by the National Research Centre, Dokki, Cairo, Egypt project \# 12050305.

\section{Competing interests}

The authors declare that they have no competing interests

\section{Availability of data and materials}

Data are available on request to the authors

\section{References}

Abdel-Wahhab MA, Abdel-Galil MM, Hassan AM, Hassan NH, Nada SA, Saeed A, El-Sayed MM (2007) Zizyphus spina-christi extract protects against aflatoxin $\mathrm{B}_{1}$-intitiated hepatic carcinogenicity Afr. J. Trad. CAM. 4 (3): 248-256.

Abdel-Wahhab MA, El-Nekeety AA, Hassan NS, Gibriel AA, Abdel-Wahhab KG (2018) Encapsulation of cinnamon essential oil in whey protein enhances the protective effect against single or comined subchronic toxicity of fumonisin $B_{1}$ and/or aflatoxin $B_{1}$ in rats. Environ. Sci. pollu. Res. 25(29): 29144-29161.

Adams RP (2007) Identification of essential oil components by gas chromato-graphy/mass spectroscopy. Allured Publishing Crop, Carol Stream, Illinois, USA. 432. 
Ahmad A, van Vuuren S, Viljoen A (2014) Unravelling the complex antimicrobial interactions of essential oils, the case of Thymus vulgaris (thyme). Molecules (Basel, Switzerland), 19(3): 2896-2910.

Ahmed AA, Fedail JS, Musa HH, Kamboh AA, Sifaldin AZ, Musa TH (2015) Gum Arabic extracts protect against hepatic oxidative stress in alloxan induced diabetes in rats. Pathophysiol. 22: 189-194.

Alam K, Nagi MN Badary OA, AL-Shabanah OA, AL-Rikabi AC, AL-Bekairi AM (1999) The protective action of thymol against carbon tetrachloride hepatotoxicity in mice. Pharmacol. Res. 40(2): 159-163.

Al-Fartosi KG, Khuon OS, Al-Tae HI (2011) Protective role of camel's milk against paracetamol induced hepatotoxicity in male rats. Int. J. Res. Pharma. Biomed. Sci. 2: 1795-1799.

Ali BH, Al-Salam S, Al Husseni I, Kayed RR, Al-Masroori N, Al-Harthi T, Al Zaabi M, Nemmar A (2010) Effects of gum Arabic in rats with adenine-induced chronic renal failure. Exp. Biol. Med. 235(3): 373- 382.

Ali BH, Beegam I Al-Lawati M, Waly MI, Al Za'abi M, Nemmar A (2013) Comparative efficacy of three brands of gum acacia on adenine-induced chronic renal failure in rats. Physiol. Res. 62 (62): 47-56.

Ali NE, Kaddam LA, Alkarib SY, Kaballo BG, Khalid SA, Higawee A, AbdElhabib A, AlaaAldeen A, Phillips AO, Saeed AM (2020) Gum arabic (Acacia Senegal) augmented total antioxidant capacity and reduced Creactive protein among haemodialysis patients in phase II trial. Int. J. Nephrol. 2020: 7214673.

Allouche L, Hamadouche M, Touabti A, Khennouf S (2011) Effect of long-term exposure to low or moderate lead concentrations on growth, lipid profile and liver function in albino rats. Advan. Biol. Res. 5(6): 339-347.

Almansour MI, Alferah MA, Shraideh ZA, Jarrar BM (2017) Zinc oxide nanoparticles hepatotoxicity: histological and histochemical study. Environ. Toxicol. Pharmacol. 51: 124-130.

Al-Yahya AA, Al-Majed AA, Gado AM, Daba MH, Al-Shabanah OA, El-Azab AS, Abd-Allah AR (2009) Acacia senega/ gum exudate offers protection against cyclophosphamide-induced urinary bladder cytotoxicity. Oxid. Med. Cell Longev. 2 (4): 207-213.

Arunasree KM (2010) Anti-proliferative effects of carvacrol on a human metastatic breast cancer cell line, MDA-MB 231. Phytomed. 17(8-9): 581-588.

Aydın S, Başaran AA, Başaran N (2005) The effects of thyme volatiles on the induction of DNA damage by the heterocyclic amine IQ and mitomycin C. Mutat. Res. 581: 43-53.

Bala N, Saha S, Chakraborty M, Maiti M, Das S, Basu R, Nandy P (2015) Green synthesis of zinc oxide nanoparticles using Hibiscus subdariffa leaf extract: effect of temperature on synthesis, anti-bacterial activity and anti-diabetic activity. RSC Adv. 5: 4993-5003. 
Bayrama T, Pekmez M, Arda N, Yalcın AS (2009) Antioxidant activity of whey protein fractions isolated by gel exclusion chromatography and protease treatment. Talanta 75: 705-709.

Bhalla Y, Gupta VK, Jaitak V (2013) Anticancer activity of essential oils: a review. J. Sci. Food Agric. 93: 3643-3653.

Borugă O, Jianu C, Mişcă C, Goleţ I, Gruia AT, Horhat FG (2014) Thymus vulgaris essential oil: chemical composition and antimicrobial activity. J. Med. Life. 7(3): 56-60.

Bounous G, Gervais F, Amer V, Batist G, Gold P (1989) The influence of dietary whey protein on tissue glutathione and disease of aging. Clin. Invest. Med. 12: 343-349.

De Andrade TU, Brasil GA, Endringer DC, Da Nobrega FR, De Sousa DP (2017) Cardiovascular activity of the chemical constituents of essential oils. Molecules 22(9): 1539.

Diab AA, Zahralh MH, AL-dohim SI, Hassan NJ (2015) The impact of Moringaoleifera extract and vitamin E against zinc oxide nanoparticles induced hepatotoxicity in male albino rats. J. Am. Sci. 11 (5): 185-197.

Diab KA, Fahmy MA, Hassan ZM, Hassan EM, Salama AB, Omara EA (2018) Genotoxicity of carbon tetrachloride and the protective role of essential oil of Salvia officinalis $L$. in mice using chromosomal aberration. micronuclei formation and comet assay. Environ. Sci. Pollut. Res. 25: 1621-1636.

Dillioglugil MO, Mekık H, Muezzinoglu B, Ozkan TA, Demir CG, Dillioglugil O (2012) Blood and tissue nitric oxide and malondialdehyde are prognostic indicators of localized prostate cancer. Int. Urol. Nephrol. 44(6): 1691-1696.

Drury, R.A.V., Wallington, E.A., 1980. Carltons Histological Techniques, $5^{\text {th }}$ ed. Oxford University Press, New York, Pronto, pp. 206.

Ebenyi LN, Ibiam UA, Aja PM (2012) Effects of Allium sativum extract on paracetamol-induced hepatotoxicity in albino rats. IRJBB 2: 93-97.

Edet E, Ofem J, Igile G, Ofem O, Zainab D, Akwaowo G (2015) Antioxidant capacity of different African seeds and vegetables and correlation with the contents of ascorbic acid, phenolics and flavonoids. J. Med. Plant Res. 9: 454-61.

El-Banna H, Solimanand M, Al-Wabel N (2013) Hepatoprotective effects of Thymus and Salvia essential oils on paracetamol induced toxicity in rats. J. Phys. Pharm. Adv. 3: 41-47.

El-Nekeety AA, Mohamed SR, Hathout AS, Hassan NS, Aly SE, Abdel-Wahhab MA (2011) Antioxidant properties of Thymus vulgaris oil against aflatoxin-induce oxidative stress in male rats. Toxicon 57: 984991. 
Esparza-Gonzalez SC, Sanchez-Valdes S, Ramirez-Barron SN, Loera-Arias MJ, Bernal J, Melendez-Ortiz HI, Betancourt-Galindo R (2016) Effects of different surface modifying agents on the cytotoxic and antimicrobial properties of ZnO nanoparticles. Toxicol. in Vitro 37: 134-141.

Espitia PJP, Soares NFF, Coimbra JSR., Andrade NJ, Cruz RS, Medeiros EAA (2012) Zinc oxide nanoparticles: synthesis, antimicrobial activity and food packaging applications. Food Bioprocess Technol. 5: 1447-1464.

Fachini-Queiroz FC, Kummer R, Estevão-Silva CF, Carvalho MD, Cunha JM, Grespan R, Bersani-Amado CA, Cuman RK (2012) Effects of thymol and carvacrol, constituents of Thymus vulgaris L. essential oil, on the inflammatory response. Evid. Based Complement. Alternat. Med. 2012: 657026 doi: $10.1155 / 2012 / 657026$

Fadoju O, Ogunsuyi O, Akanni O, Alabi O, Alimba C, Adaramoye O, Cambier S, Eswara S, Gutleb AC, Bakare A (2019) Evaluation of cytogenotoxicity and oxidative stress parameters in male Swiss mice co-exposed to titanium dioxide and zinc oxide nanoparticles. Environ. Toxicol. Pharmacol. 70: 103204.

Gad AS, Khadrawy YA, El-Nekeety AA, Mohamed SR, Hassan NS, Abdel-Wahhab MA (2011) Antioxidant activity and hepatoprotective effects of whey protein and spirulina in rats. Nutr. 27(5): 582-589.

Ghosh M, Sinha S, Jothiramajayam M, Jana A, Nag A, Mukherjee A (2016) Cyto-genotoxicity and oxidative stress induced by zinc oxide nanoparticle in human lymphocyte cells in vitro and Swiss albino male mice in vivo. Food Chem. Toxicol. 97: 286-296.

Gonçalves ND, Pena FL, Sartoratto A, Derlamelina C, Duarte MCT, Antunes AEC, Prata AS (2017) Encapsulated thyme (Thymus vulgaris) essential oil used as a natural preservative in bakery product. Food Res. Int. 96: 154-160.

Grespan R, Aguiar RP, Giubilei FN, Fuso RR, Damião MJ, Silva EL, Mikcha JG, Hernandes L, Bersani Amado C, Cuman RK (2014) Hepatoprotective effect of pretreatment with Thymus vulgaris essential oil in experimental model of acetaminophen-induced injury. Evid. Based Complement. Alternat. Med. 2014: 954136-954136.

Gümüş D, Berber AA, Ada K, Aksoy H (2014) In vitro genotoxic effects of ZnO nanomaterials in human peripheral lymphocytes. Cytotechnol. 66: 317-325.

Hajiashrafi S, Motakef-Kazemi N (2018) Green synthesis of zinc oxide nanoparticles using parsley extract. Nanomed. Res. J. 3(1): 44-50.

Hashimoto K, Nakajima Y, Matsumura S, Chatani F (2010) An in vitro micronucleus assay with sizeclassified micronucleus counting to discriminate aneugens from clastogens. Toxicol In Vitro 24: 208-216.

Hesabi Nameghi A, Edalatian O, Bakhshalinejad R (2019) Effects of a blend of thyme, peppermint and eucalyptus essential oils on growth performance, serum lipid and hepatic enzyme indices, immune 
response and ileal morphology and microflora in broilers. J. Anim. Physiol. Anim. Nutr. (Berl). 103(5): 1388-1398.

Horvathova E, Sramkova M, Labaj J, Slamenova D (2006) Study of cytotoxic, genotoxic and DNAprotective effects of selected plant essential oils on human cells cultured in vitro. Neuroendocrinol. Lett. 27 (Suppl 2): 44-47.

Horvathova E, Turcaniova V, Slamenova D (2007) Comparative study of DNA-damaging and DNAprotective effects of selected components of essential plant oils in human leukemic cells K562. Neoplasma 54: 478-483.

Hossain F, Follett P, Salmieri S, Vu KD, Fraschini C, Lacroix M (2019) Antifungal activities of combined treatments of irradiation and essential oils (EOs) encapsulated chitosan nanocomposite films in in vitro and in situ conditions. Int. J. Food Microbiol. 295: 33-40.

Ipek E, Tüylü BA, Zeytinoğlu H (2003) Effects of carvacrol on sister chromatid exchanges in human lymphocyte cultures. Cytotechnol. 43: 145-148.

John S, Marpu S, Li J, Omary M, Hu Z, Fujita Y, Neogi A (2010) Hybrid zinc oxide nanoparticles for biophotonics. J. Nanosci. Nanotechnol. 10: 1707-1712.

Kamal E, Kaddam LA, Dahawi M, Osman DM, Salih AM, Alagib A, Saeed A (2018) Gum arabic fibers decreased inflammatory markers and disease severity score among rheumatoid arthritis patients, phase II Trial. Int. J. Rheumatol. 2018, Article ID 4197537: 6 pages.

Kang SH, Kwon JY, Lee JK, Seo YR (2013) Recent advances in in vivo genotoxicity testing: prediction of carcinogenic potential using comet and micronucleus assay in animal models. J. Cancer Prev. 18: 277288.

Kasamoto S, Masumori S, Tanaka J, Ueda M, Fukumuro M, Nagai M, Yamate J, Hayashi M (2017) Reference control data obtained from an in vivo comet-micronucleus combination assay using Sprague Dawley rats. Exp. Toxicol. Pathol. 69: 187-191.

Kasibhatla S, Amarante-Mendes GP, Finucane D, Brunner T, Bossy-Wetzel E, Green DR (2006) Acridine Orange/Ethidium Bromide (AO/EB) Staining to Detect Apoptosis. CSH Protoc 1: 2006 (3) doi: 10.1101/pdb.prot4493.

Kent KD, Harper WJ, Bomser JA (2003) Effect of whey protein isolate on intracellular glutathione and oxidant-induced cell death in human prostate epithelial cells. Toxicol. In Vitro 17: 27-33.

Khalid A, Khan R, Ul-Islam M, Khan T, Wahid F (2017) Bacterial cellulose-zinc oxide nanocomposites as a novel dressing system for burn wounds. Carbohydr. Polym. 164: 214-221. 
Kong H, Yang J, Zhang Y, Fang Y, Nishinari K, Phillips GO (2014) Synthesis and antioxidant properties of gum arabic- stabilized selenium nanoparticles. Int. J. Biol. Macromol. 65: 155-62.

Krol A, Pomastowski P, Rafinska K, Railean-Plugaru V, Buszewski B (2017) Zinc oxide nanoparticles: synthesis, antiseptic activity and toxicity mechanism. Adv. Colloid Interface Sci. 249: 37-52.

Lee KW, Everts H, Beynen AC (2004) Essential oils in broiler nutrition. Int. Poult. Sci. 3: 738-752.

Li CH, Shen CC, Cheng YW, Huang SH, Wu CC, Kao CC, Liao JW, Kang JJ (2012) Organ biodistribution, clearance, and genotoxicity of orally administered zinc oxide nanoparticles in mice. Nanotoxicol. 6:746756.

Li HF, Ding F, Xiao LY, Shi RN, Wang HY, Han WJ (2017) Food-derived antioxidant polysaccharides and their pharmacological potential in neurodegenerative diseases. Nutrients 9: 778 doi: $10.3390 / \mathrm{md} 17120674$.

Lin CC, Hsu YF, Lin,TC, Hsu FL, Hsu HY (1998) Antioxidant and hepatoprotective activity of Punicalagin and Punicalin on carbon tetrachloride induced liver damage in rats. J. Pharm. Pharmacol. 50: 789-794.

Llobet JM, Domingo JL, Colomina MT, Mayayo E, Corbella J (1988) Subchronic oral toxicity of zinc in rats. Bull. Environ. Contam. Toxicol. 41(1): 36-43.

Maisanaba S, Prieto Al, Puerto M, Gutierrez-Praena D, Demir E, Marcos R, Camean AM (2015) In vitro genotoxicity testing of carvacrol and thymol using the micronucleus and mouse lymphoma assays. Mutat. Res. Genet. Toxicol. Environ. Mutagen. (784-785): 37-44.

Mirghani MES, Elnour AAM, Kabbashi NA, Alam MZ, Musa KH, Abdullah A (2018) Determination of antioxidant activity of gum arabic: An exudation from two different locations. Sci. Asia 44 (2018): 179186.

Moatamed ER, Hussein AA, El-Desoky MM, Khayat Z (2019) Comparative study of zinc oxide nanoparticles and its bulk form on liver function of Wistar rat. Toxicol. Ind. Health 35(10): 627-637.

Mohammed KAA, Ahmed HMS, Sharaf HA, El-Nekeety AA, Abdel-Aziem SH, Mehaya FM, Abdel-Wahhab MA (2020) Encapsulation of cinnamon oil in whey protein counteracts the disturbances in gene expression and diabetic complications in rats. Environ. Sci. Pollut. Res. Int. 27: 2829-2843.

Morr CV, Ha EYW (1993) Whey protein concentrates and isolate processing and functional properties. Crit. Rev. Food Sci. Nutr. 33: 431-476.

Mudunkotuwa IA, Rupasinghe T, Wu CM, Grassian VH (2012) Dissolution of ZnO nanoparticles at circumneutral pH: a study of size effects in the presence and absence of citric acid. Langmuir 28: 396403. 
Müller P, Schmid M (2019) Intelligent Packaging in the Food Sector: A Brief Overview. Foods (Basel, Switzerland), 8(1): 16. https://doi.org/10.3390/foods8010016

Pati R, Das I, Mehta RK, Sahu R, Sonawane A (2016) Zinc-oxide nanoparticles exhibit genotoxic, clastogenic, cytotoxic and actin depolymerization effects by inducing oxidative stress responses in macrophages and adult mice. Toxicol. Sci. 150: 454-472.

Pourmirzaiee MA, Chehrazi S, Heidari-Beni M, Kelishadi R (2018) Serum zinc level and eating behaviors in children receiving zinc supplements without physician prescription. Adv. Biomed. Res. 7: 120. doi: 10.4103/abr.abr_77_18.

Prasad AS (2008) Clinical, immunological, anti-inflammatory and antioxidant roles of zinc. Exp. Gerontol. $43(5): 370-377$.

Rasmussen JW, Martinez E, Louka P, Wingett DG (2010) Zinc oxide nanoparticles for selective destruction of tumor cells and potential for drug delivery applications. Expert Opin. Drug Deliv. 7: 1063-1077.

Razzaghi-Abyaneh M, Shams-Ghahfarokhi M, Rezaee M, Jaimand K, Alinezhad S, Saberi R, Yoshinar T (2009) Chemical composition and antiaflatoxigenic activity of Carum carvi L., Thymus vulgaris and Citrus aurantifolia essential oils. Food Cont. 20: 1018-1024.

Reis Éde M, de Rezende AA, Santos DV, de Oliveria PF, Nicolella HD, Tavares DC, Silva AC, Dantas NO, Spanó MA (2015) Assessment of the genotoxic potential of two zinc oxide sources (amorphous and nanoparticles) using the in vitro micronucleus test and the in vivo wing somatic mutation and recombination test. Food Chem. Toxicol. 84: 55-63.

Rojas-Armas J, Arroyo-Acevedo J, Ortiz-Sánchez M, Palomino-Pacheco M, Castro-Luna A, Ramos-Cevallos $\mathrm{N}$, Justil-Guerrero H, Hilario-Vargas J, Herrera-Calderón $\mathrm{O}$ (2019) Acute and repeated 28-day oral dose toxicity studies of Thymus vulgaris $L$. essential oil in rats. Toxicol. Res. 35: 225-232.

Rota MCA, Herrera RM, Martinez JA, Sotomayor M, Jordan MJ (2007) Antimicrobial activity and chemical composition of Thymus vulgaris, Thymus zygis and Thymus hyemalisessential oils. Food Cont. 19: 681687.

Sahu N, Saxena J (2013) Different methods for determining antioxidant activity: a review. Indo. Am. J. Pharma. Res. 3: 7025-7028.

Saliani M, Jalal R, Goharshadi EK (2016) Mechanism of oxidative stress involved in the toxicity of ZnO nanoparticles against eukaryotic cells. Nanomed. J. 3(1): 1-14.

Sha B, Gao W, Wang S, Gou X, Li W, Liang X, Qu Z, Xu F, Lu TJ (2014) Oxidative stress increased hepatotoxicity induced by nano-titanium dioxide in BRL-3A cells and Sprague-Dawley rats. J. Appl. Toxicol. 34(4): 345-356. 
Shaban EE, Elbakry HFH, Ibrahim KS, El Sayed EM, Salama DM, Farrag AH (2019) The effect of white kidney bean fertilized with nano-zinc on nutritional and biochemical aspects in rats. Biotechnol. Rep. (Amst). 23: e00357. doi: 10.1016/ j. btre. 2019.e00357.

Shalini D, Senthilkumar S, Rajaguru P (2018) Effect of size and shape on toxicity of zinc oxide (ZnO) nanomaterials in human peripheral blood lymphocytes. Toxicol. Mech. Methods 28; 87-94.

Sharma V, Anderson D, Dhawan A (2011) Zinc oxide nanoparticles induce oxidative stress and genotoxicity in human liver cells (HepG2). J. Biomed. Nanotechnol. 7: 98-99.

Sharma V, Anderson D, Dhawan A (2012) Zinc oxide nanoparticles induce oxidative DNA damage and ROS-triggered mitochondria mediated apoptosis in human liver cells (HepG2). Apoptosis 17(8): 852-870.

Singh A, Bhat TK, Sharma OP (2001) Clinical biochemistry of hepatotoxicity. J. Clinic. Toxicol. S4: 1-19.

Singh S (2019) Zinc oxide nanoparticles impacts: cytotoxicity, genotoxicity, developmental toxicity, and neurotoxicity. Toxicol. Mech Methods 29: 300-311.

Soni D, Gandhi D, Tarale P, Bafana A, Pandey RA, Sivanesan S (2017) Oxidative stress and genotoxicity of zinc oxide nanoparticles to Pseudomonas species, human promyelocytic leukemic (HL-60), and blood cells. Biol. Trace Elem. Res. 178: 218-227.

Srivastav AK, Kumar M, Ansari NG, Jain AK, Shankar J, Arjaria N, Jagdale P, Singh D (2016) A comprehensive toxicity study of zinc oxide nanoparticles versus their bulk in Wistar rats: Toxicity study of zinc oxide nanoparticles. Hum. Exp. Toxicol. 35(12): 1286-1304.

Stan M, Popa A, Toloman D, Silipas T, Vodnar DC, Katona G (2015) Enhanced antibacterial activity of zinc oxide nanoparticles synthesized using Petroselinum crispum extracts. AIP Conference Proceedings 1700: 060004. doi.org/10.1063/1.4938454.

Syama S, Sreekanth PJ, Varma HK, Mohanan PV (2014) Zinc oxide nanoparticles induced oxidative stress in mouse bone marrow mesenchymal stem cells. Toxicol. Mech. Methods 24: 644-653.

Tang HQ, Xu M, Rong Q, Jin RW, Liu QJ, Li YL (2016) The effect of ZnO nanoparticles on liver function in rats. Int. J. Nanomed. 11: 4275-85.

Tian L, Lin B, Lei WL, Li K, Liu H, Yan J, Liu X, Zhuge X (20150 Neurotoxicity induced by zinc oxide nanoparticles: age-related differences and interaction. Sci. Rep. 5: 16117.

Toujani MM, Rittà M, Civra A, Genovese S, Epifano F, Ghram A, Lembo D, Donalisio M (2018) Inhibition of HSV-2 infection by pure compounds from Thymus capitatus extract in vitro. Phytother. Res. 32(8): 15551563. 
Tomazelli Júnior O, Kuhn F, Padilha PJM, Vicente LRM, Costa SW, Boligon AA, Scapinellob J, Nesi CN, Dal Magrob J, Lamo Castellví S (2018). Microencapsulation of essential thyme oil by spray drying and its antimicrobial evaluation against Vibrio alginolyticus and Vibrioparahaemolyticus. Braz. J. Biol. 78(2): 311-317.

Turkez H, Aydin E (2016) Investigation of cytotoxic, genotoxic and oxidative properties of carvacrol in human blood cells. Toxicol. Ind. Health. 32: 625-633.

Ündeğer U, Basaran A, Degen GH, Basaran N (2009) Antioxidant activities of major thyme ingredients and lack of (oxidative) DNA damage in V79 Chinese hamster lung fibroblast cells at low levels of carvacrol and thymol. Food Chem. Toxicol. 47: 2037-2043.

Ushida K, Hatanaka H, Inoue R, Tsukahara T, Phillips GO (2011) Effect of long-term ingestion of gum arabic on the adipose tissues of female mice. Food Hydrocoll. 25(5): 1344-1349.

Vasquez MZ (2010) Combining the in vivo comet and micronucleus assays: a practical approach to genotoxicity testing and data interpretation. Mutagenesis 25: 187-199.

Wang B, Feng W, Wang M, Wang T, Gu Y, Zhu M, Ouyang H, Shi J, Zhang F, Zhao Y, Chai Z, Wang H, Wang $\mathrm{J}$ (2008) Acute toxicological impact of nano- and submicro-scaled zinc oxide powder on healthy adult mice. J. Nanopart. Res. 10: 263-276.

Wang B, Fenga WY, Wang TC, Jia G, Wang M, Shi JW, Zhang F, Zhao YL, Chai ZF (2006) Acute toxicity of nano- and micro-scale zinc powder in healthy adult mice. Toxicol. Lett. 161: 115-123.

Wang B, Zhang J, Chen C, Xu G, Qin X, Hong Y, Bose DD, Qiu F, Zou Z (2018) The size of zinc oxide nanoparticles controls its toxicity through impairing autophagic flux in A549 lung epithelial cells. Toxicol. Lett. 285: 51-59.

Wang B, Zhang Y, Mao Z, Yu D, Gao C (2014) Toxicity of ZnO nanoparticles to macrophages due to cell uptake and intracellular release of zinc ions. J. Nanosci. Nanotechnol. 14: 5688-5696.

Wang M, Wang J, Liu Y, Wang J, Nie Y, Si B, Liu Y, Wang X, Chen S, Hei TK, Wu L, Zhao G, Xu A (2019) Subcellular targets of zinc oxide nanoparticles during the aging process: role of cross-talk between mitochondrial dysfunction and endoplasmic reticulum stress in the genotoxic response. Toxicol. Sci. pii: kfz132. doi: 10.1093/toxsci/kfz132.

Wang Y, Yuan L, Yao C, Ding L, Li C, Fang J, Sui K, Liu Y, Wu M (2014a) A combined toxicity study of zinc oxide nanoparticles and vitamin $C$ in food additives. Nanoscale 6(24): 15333-15342.

Wang JQ, Hu SZ, Nie SP, Yu Q, Xie MY (2016) Reviews on mechanisms of in vitro antioxidant activity of polysaccharides. Oxid. Med. Cell. Longev. 2016: 5692852 
Wang ZJ, Xie J, Nie SP, Xie MY (2017) Review on cell models to evaluate potential antioxidant activity of polysaccharides. Food Funct. 8: 915-926.

Wessels I, Rolles B, Rink L (2020) The potential impact of zinc supplementation on COVID-19 pathogenesis. Front. Immunol.11: 1712. doi:10.3389/fimmu. 2020. 01712.

Wu B, Wang Y, Lee YH, Horst A, Wang Z, Chen DR, Sureshkumar R, Tang YJ (2010) Comparative ecotoxicities of nano-ZnO particles under aquatic and aerosol exposure modes. Environ. Sci. Technol. 44(4) : 1484-1489.

Yan Y, Wang G, Huang J, Zhang Y, Cheng X, Chuai M, Brand-Saberi B, Chen G, Jiang X, Yang X (2020) Zinc oxide nanoparticles exposure-induced oxidative stress restricts cranial neural crest development during chicken embryogenesis. Ecotoxicol. Environ. Saf. 194: 110415. doi: 10.1016/j.ecoenv. 2020.110415.

Yang ST, Liu JH, Wang J, Yuan Y, Cao A, Wang H, Liu Y, Zhao Y (2010) Cytotoxicity of zinc oxide nanoparticles: importance of microenvironment. J. Nanosci. Nanotechnol. 10(12): 8638-8645.

Zarria-Romero J, Osorio A, Pino J, Shiga B, Vivas-Ruiz D (2017) Effect of the industrial nanoparticles $\mathrm{TiO}_{2}$ , $\mathrm{SiO}_{2}$ and $\mathrm{ZnO}$ on cell viability and gene expression in red bone marrow of Mus Musculus. Rev. Peru.

Med. Exp. Salud. Publica. 34: 436-444.

Zhong Q, Wei B, Wang S, Ke S, Chen J, Zhang H, Wang H (2019) The antioxidant activity of polysaccharides derived from marine organisms: An overview. Mar. Drugs 17(12): 674. doi: $10.3390 / \mathrm{md} 17120674$.

\section{Tables}

Table 1Chemical constitutes of ETO identified by GC-MS

\begin{tabular}{lcl}
\hline \multicolumn{1}{c}{ Constituents* } & $\mathrm{mg} / \mathrm{g}$ & Class \\
\hline Carvacrol & 45.8 & Phenols \\
Thymol & 25.70 & Phenols \\
$\beta$-Phellandrene & 10.20 & Terpene \\
Linalool & 5.10 & Terpene \\
Humuline & 3.70 & Sesquiterpene \\
$\alpha$ - Phellandrene & 2.40 & Terpene \\
Myrcene & 2.12 & Terpene \\
$\beta$ - pinene & 1.51 & Terpene \\
1, 8-cineole & 1.56 & Oxides \\
$\alpha$-pinene & 1.41 & Terpene \\
$\beta$-sabinene & 1.34 & Terpene \\
$\alpha$-thyjone & 1.35 & Oxygenated terpene \\
Tricyclene & 1.11 & Terpene \\
Total & 103.3 & \\
\hline
\end{tabular}

*Constituents presented in the order of concentration

Table 2 Effect of ETO at low or high dose on serum biochemical parameters in rats treated with ZnO-NPs 


\begin{tabular}{|c|c|c|c|c|c|c|}
\hline $\begin{array}{l}\text { Groups } \\
\text { Parameter }\end{array}$ & Control & ZnO-NPs & $\begin{array}{l}\text { ETO } \\
\text { (LD) }\end{array}$ & $\begin{array}{l}\text { ETO } \\
\text { (HD) }\end{array}$ & $\begin{array}{c}\text { ZnO-NPs + } \\
\text { ETO (LD) }\end{array}$ & $\begin{array}{c}\text { ZnO-NPs + } \\
\text { ETO (HD) }\end{array}$ \\
\hline \multirow[t]{2}{*}{ ALT (U/L) } & $53.60 \pm$ & $71.80 \pm$ & $51.00 \pm$ & $51.00 \pm$ & $58.58 \pm$ & $46.60 \pm$ \\
\hline & $1.17^{\mathrm{a}}$ & $0.97^{\mathrm{b}}$ & $2.43^{\mathrm{a}}$ & $1.34^{\mathrm{a}}$ & $3.12^{\mathrm{c}}$ & $2.16^{\mathrm{d}}$ \\
\hline \multirow[t]{2}{*}{ AST (U/L) } & $134.80 \pm 1.39^{a}$ & $173.60 \pm 4.30^{\mathrm{b}}$ & $134.40 \pm$ & $134.60 \pm$ & $139.60 \pm$ & $133.60 \pm$ \\
\hline & & & $0.81^{\mathrm{a}}$ & $1.44^{\mathrm{a}}$ & $1.63^{\mathrm{c}}$ & $2.38^{\mathrm{a}}$ \\
\hline \multirow[t]{2}{*}{ Alb (g/dl) } & $6.56 \pm$ & $5.26 \pm$ & $7.36 \pm$ & $7.04 \pm$ & $7.30 \pm$ & $6.62 \pm$ \\
\hline & $0.17^{\mathrm{a}}$ & $0.33^{\mathrm{b}}$ & $0.14^{\mathrm{C}}$ & $0.07^{\mathrm{ac}}$ & $0.13^{\mathrm{c}}$ & $0.08^{\mathrm{a}}$ \\
\hline \multirow[t]{2}{*}{$\mathrm{TP}(\mathrm{g} / \mathrm{dl})$} & $6.20 \pm$ & $5.65 \pm$ & $6.20 \pm$ & $6.20 \pm$ & $5.76 \pm$ & $5.26 \pm$ \\
\hline & $0.16^{\mathrm{a}}$ & $0.13^{b}$ & $0.13^{\mathrm{a}}$ & $0.15^{\mathrm{a}}$ & $0.28^{\mathrm{a}}$ & $0.33^{\mathrm{c}}$ \\
\hline \multirow[t]{2}{*}{ Creatinine $(\mathrm{mg} / \mathrm{dl})$} & $0.54 \pm$ & $0.98 \pm$ & $0.60 \pm$ & $0.60 \pm$ & $0.62 \pm$ & $0.56 \pm$ \\
\hline & $0.02^{\mathrm{a}}$ & $0.02^{\mathrm{b}}$ & $0.04^{\mathrm{c}}$ & $0.03^{\mathrm{c}}$ & $0.04^{\mathrm{c}}$ & $0.05^{\mathrm{a}}$ \\
\hline \multirow[t]{2}{*}{ Uric acid (mg/dl) } & $5.70 \pm$ & $6.80 \pm$ & $5.94 \pm$ & $6.26 \pm$ & $5.98 \pm$ & $5.80 \pm$ \\
\hline & $0.70^{\mathrm{a}}$ & $0.16^{\mathrm{b}}$ & $0.12^{\mathrm{a}}$ & $0.31^{\mathrm{c}}$ & $0.14^{\mathrm{a}}$ & $0.10^{\mathrm{a}}$ \\
\hline \multirow[t]{2}{*}{ Urea $(\mathrm{mg} / \mathrm{dl})$} & $35.0 \pm$ & $53.6 \pm$ & $33.6 \pm$ & $34.2 \pm$ & $46.2 \pm$ & $36.8 \pm$ \\
\hline & $0.71^{\mathrm{a}}$ & $1.44^{\mathrm{b}}$ & $1.83^{\mathrm{a}}$ & $1.24^{\mathrm{a}}$ & $0.86^{\mathrm{c}}$ & $1.16^{\mathrm{a}}$ \\
\hline
\end{tabular}

Within each raw, means superscripts with different letters are significantly different $(\mathrm{P}<0.05)$

Table 3 Effects of ETO on lipid profile in rats treated with ZnO-NPs

\begin{tabular}{lcccc}
\hline proups & $\begin{array}{c}\text { parameter } \\
(\mathrm{mg} / \mathrm{dl})\end{array}$ & $\begin{array}{c}\text { Tri G } \\
(\mathrm{mg} / \mathrm{dl})\end{array}$ & $\begin{array}{c}\text { HDL } \\
(\mathrm{mg} / \mathrm{dl})\end{array}$ & $\begin{array}{c}\text { LDL } \\
(\mathrm{mg} / \mathrm{dl})\end{array}$ \\
\hline Control & $61.40 \pm 1.96^{\mathrm{a}}$ & $131.60 \pm 2.06^{\mathrm{a}}$ & $48.00 \pm 1.34^{\mathrm{a}}$ & $6.16 \pm 0.35^{\mathrm{a}}$ \\
ZnO-NPs & $80.20 \pm 3.71^{\mathrm{b}}$ & $145.40 \pm 0.51^{\mathrm{b}}$ & $31.00 \pm 1.38^{\mathrm{b}}$ & $7.12 \pm 0.79^{\mathrm{b}}$ \\
ETO (LD) & $51.00 \pm 1.14^{\mathrm{c}}$ & $133.80 \pm 1.46^{\mathrm{a}}$ & $50.40 \pm 2.25^{\mathrm{c}}$ & $6.08 \pm 0.58^{\mathrm{a}}$ \\
ETO (HD) & $48.20 \pm 2.60^{\mathrm{c}}$ & $119.20 \pm 3.22^{\mathrm{c}}$ & $52.40 \pm 1.44^{\mathrm{ac}}$ & $6.03 \pm 0.71^{\mathrm{a}}$ \\
ZnO-NPs + ETO (LD) & $66.40 \pm 1.69^{\mathrm{d}}$ & $138.00 \pm 1.38^{\mathrm{d}}$ & $45.40 \pm 1.12^{\mathrm{d}}$ & $6.68 \pm 0.43^{\mathrm{c}}$ \\
ZnO-NPs + ETO (HD) & $64.60 \pm 1.72^{\mathrm{d}}$ & $134.40 \pm 4.76^{\mathrm{a}}$ & $47.20 \pm 1.53^{\mathrm{a}}$ & $6.48 \pm 0.24^{\mathrm{c}}$ \\
\hline
\end{tabular}

Within each column, means superscripts with different letters are significantly different $(P<0.05)$

Table 4 Effects of ETO on antioxidant parameters in rats treated with ZnO-NPs

\begin{tabular}{|c|c|c|c|c|c|c|}
\hline \multirow[t]{2}{*}{ Groups } & \multicolumn{2}{|c|}{$\begin{array}{c}\text { TAC } \\
(\mu \mathrm{M} / \mathrm{g} \text { tissue })\end{array}$} & \multicolumn{2}{|c|}{$\begin{array}{c}\text { CAT } \\
\text { (mU/g tissue) }\end{array}$} & \multicolumn{2}{|c|}{$\begin{array}{c}\text { SOD } \\
\text { (U/g tissue) }\end{array}$} \\
\hline & Liver & Kidney & Liver & Kidney & Liver & Kidney \\
\hline Control & $27.32 \pm 1.34^{\mathrm{a}}$ & $26.89 \pm 1.52^{\mathrm{a}}$ & $10.23 \pm 1.03^{\mathrm{a}}$ & $9.32 \pm 0.15^{\mathrm{a}}$ & $35.42 \pm 1.37^{a}$ & $31.21 \pm 1.56^{\mathrm{a}}$ \\
\hline $\mathrm{ZnO}-\mathrm{NPs}$ & $20.28 \pm 1.58^{b}$ & $13.06 \pm 0.27^{b}$ & $6.25 \pm 0.43^{b}$ & $6.33 \pm 0.53^{b}$ & $18.22 \pm 1.42^{b}$ & $16.37 \pm 1.41^{b}$ \\
\hline ETO (LD) & $27.65 \pm 0.70^{a}$ & $24.55 \pm 1.73^{\mathrm{c}}$ & $10.66 \pm 0.42^{\mathrm{a}}$ & $9.44 \pm 0.43^{\mathrm{a}}$ & $36.14 \pm 1.44^{\mathrm{a}}$ & $33.35 \pm 0.73^{a}$ \\
\hline ETO (HD) & $28.32 \pm 0.67^{a}$ & $25.9 \pm 2.45^{\mathrm{a}}$ & $11.32 \pm 0.54^{\mathrm{c}}$ & $9.78 \pm 0.44^{\mathrm{a}}$ & $38.72 \pm 1.23^{\mathrm{c}}$ & $33.23 \pm 1.31^{\mathrm{a}}$ \\
\hline ZnO-NPs + ETO (LD) & $23.77 \pm 0.35^{c}$ & $17.83 \pm 0.59^{d}$ & $7.26 \pm 0.75^{d}$ & $8.23 \pm 0.63^{c}$ & $25.33 \pm 1.47^{d}$ & $23.42 \pm 1.37^{\mathrm{C}}$ \\
\hline ZnO-NPs + ETO (HD) & $25.36 \pm 0.67^{d}$ & $25.87 \pm 1.59^{\mathrm{a}}$ & $8.12 \pm 0.32^{\mathrm{e}}$ & $9.21 \pm 0.52^{\mathrm{a}}$ & $33.43 \pm 1.32^{\mathrm{a}}$ & $26.77 \pm 1.32^{\mathrm{d}}$ \\
\hline
\end{tabular}

Within each column, means superscripts with different letters are significantly different $(\mathrm{P}<0.05)$

Table 5 Effects of ETO on MDA and NO in rats treated with ZnO-NPs 


\begin{tabular}{|c|c|c|c|c|}
\hline \multirow{3}{*}{ Groups } & \multirow{2}{*}{\multicolumn{2}{|c|}{$\begin{array}{c}\mathrm{NO} \\
(\mu \mathrm{mol} / \mathrm{g} \text { tissue })\end{array}$}} & \multirow{2}{*}{\multicolumn{2}{|c|}{$\begin{array}{c}\text { MDA } \\
\text { (nmol/g tissue) }\end{array}$}} \\
\hline & & & & \\
\hline & Liver & Kidney & Liver & Kidney \\
\hline Control & $2.55 \pm 0.09^{\mathrm{a}}$ & $2.17 \pm 0.04^{\mathrm{a}}$ & $37.96 \pm 3.31^{\mathrm{a}}$ & $89.06 \pm 1.80^{\mathrm{a}}$ \\
\hline $\mathrm{ZnO}-\mathrm{NPs}$ & $5.43 \pm 0.07^{b}$ & $4.53 \pm 0.24^{b}$ & $81.74 \pm 0.17^{b}$ & $180.04 \pm 2.61^{b}$ \\
\hline ETO (LD) & $2.57 \pm 0.06^{\mathrm{a}}$ & $2.18 \pm 0.08^{\mathrm{a}}$ & $35.78 \pm 2.70^{\mathrm{a}}$ & $84.54 \pm 5.51^{\mathrm{c}}$ \\
\hline ETO (HD) & $2.54 \pm 0.08^{\mathrm{a}}$ & $2.25 \pm 0.21^{\mathrm{a}}$ & $33.2 \pm 7.40^{\mathrm{C}}$ & $81.98 \pm 3.95^{c}$ \\
\hline ZnO-NPs + ETO (LD) & $3.98 \pm 0.03^{c}$ & $2.88 \pm 0.13^{\mathrm{ac}}$ & $44.7 \pm 2.01^{\mathrm{d}}$ & $125.60 \pm 4.98^{d}$ \\
\hline ZnO-NPs + ETO (HD) & $3.11 \pm 0.11^{\mathrm{c}}$ & $2.32 \pm 0.32^{\mathrm{ac}}$ & $33.67 \pm 1.60^{\mathrm{C}}$ & $95.87 \pm 7.63^{a}$ \\
\hline
\end{tabular}

Within each column, means superscripts with different letters are significantly different $(\mathrm{P}<0.05)$

'able 6 Effects of ETO on serum cytokines in rats treated with ZnO-NPs

\begin{tabular}{|c|c|c|c|}
\hline parameter & $\begin{array}{c}\text { AFP } \\
\text { (ng/ml) }\end{array}$ & $\begin{array}{l}\mathrm{TNF}-\alpha \\
(\mathrm{ng} / \mathrm{ml})\end{array}$ & $\begin{array}{c}\text { CEA } \\
(\mathrm{ng} / \mathrm{ml})\end{array}$ \\
\hline Control & $0.03 \pm 0.01^{\mathrm{a}}$ & $0.27 \pm 0.01^{\mathrm{a}}$ & $2.57 \pm 0.07^{a}$ \\
\hline ZnO-NPs & $0.07 \pm 0.00^{b}$ & $0.39 \pm 0.04^{b}$ & $2.76 \pm 0.22^{b}$ \\
\hline ETO (LD) & $0.03 \pm 0.01^{\mathrm{a}}$ & $0.25 \pm 0.02^{\mathrm{c}}$ & $1.54 \pm 0.15^{\mathrm{c}}$ \\
\hline ETO (HD) & $0.03 \pm 0.01^{\mathrm{a}}$ & $0.24 \pm 0.02^{\mathrm{c}}$ & $1.48 \pm 0.22^{\mathrm{C}}$ \\
\hline ZnO-NPs + ETO (LD) & $0.23 \pm 0.17^{\mathrm{c}}$ & $0.25 \pm 0.02^{\mathrm{c}}$ & $1.77 \pm 0.08^{d}$ \\
\hline ZnO-NPs + ETO (HD) & $0.04 \pm 0.03^{d}$ & $0.27 \pm 0.01^{\mathrm{a}}$ & $1.08 \pm 0.06^{\mathrm{e}}$ \\
\hline
\end{tabular}

Within each column, means superscripts with different letters are significantly different $(\mathrm{P}<0.05)$

Table 7 Effect of ETO on the incidence of micronucleated polychromatic erythrocytes (MNPCE) and erythroblast cytotoxicity in rats treated with $\mathrm{ZnO}-\mathrm{NPs}$

\begin{tabular}{lccc}
\hline \multirow{2}{*}{ Experimental groups } & \multicolumn{2}{c}{ NO. and \% of MNPCE/2000 PCEs } & PCE/(NCE+PCE) \\
\cline { 2 - 4 } & NO. & Mean \% \pm SE & Mean \% \pm SE \\
\hline Control & 13 & $0.13 \pm 0.03^{\mathrm{a}}$ & $0.48 \pm 0.02^{\mathrm{a}}$ \\
ZnO-NPs & 109 & $1.09 \pm 0.10^{\mathrm{d}}$ & $0.47 \pm 0.02^{\mathrm{a}}$ \\
\hline ETO (LD) & 20 & $0.20 \pm 0.04^{\mathrm{ab}}$ & $0.44 \pm 0.01^{\mathrm{a}}$ \\
\hline ETO (HD) & 23 & $0.23 \pm 0.03^{\mathrm{ab}}$ & $0.46 \pm 0.03^{\mathrm{a}}$ \\
\hline ZnO-NPs + ETO (LD) & 33 & $0.46 \pm 0.04^{\mathrm{c}}$ & $0.45 \pm 0.03^{\mathrm{a}}$ \\
\hline ZnO-NPs + ETO (HD) & 46 & $0.33 \pm 0.04^{\mathrm{bc}}$ & $0.49 \pm 0.02^{\mathrm{a}}$ \\
\hline
\end{tabular}

Total 10000 PCEs were analyzed per group (2000 PCE were analyzed per rat; 5 rats/ group). The means \% with different superscript letters are statistically significant different $(\mathrm{P}<0.05)$ using ANOVA followed by Duncan's multiple comparisons test. Within each column, means superscripts with different letters are significantly different $(\mathrm{P}<0.05)$

\section{Figures}



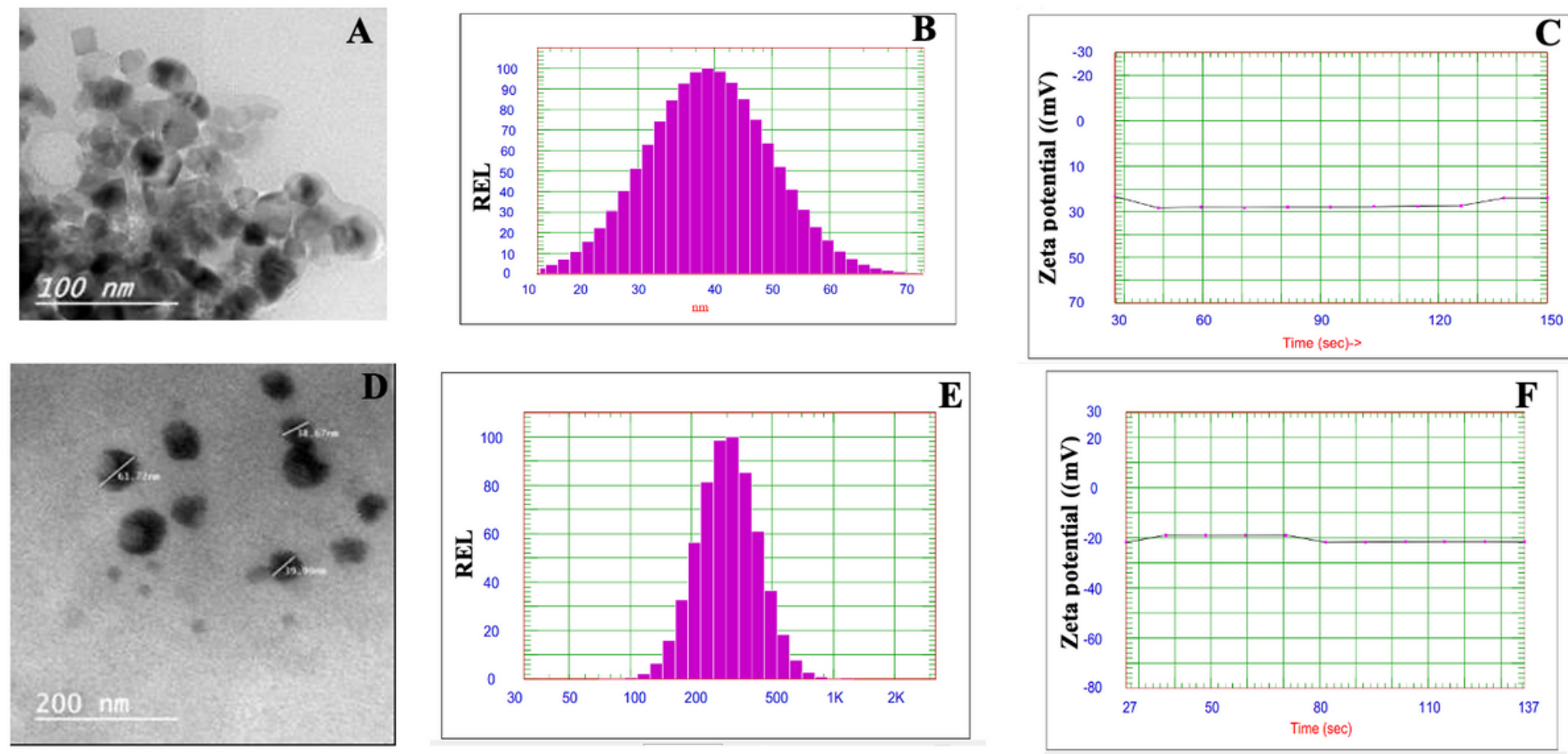

\section{Figure 1}

(A) TEM image of ETO showing the particle shape and size, (B) DLS analysis showing the size distribution of ETO, (C) ZetaSizer chromatogram showing the zeta potential of ECO, (D) particle size of ZnO-NPs, (E) DLS analysis showing particles distribution of ZnO-NPs and (F) ZetaSizer chromatogram showing the zeta potential of ZnO-NPs

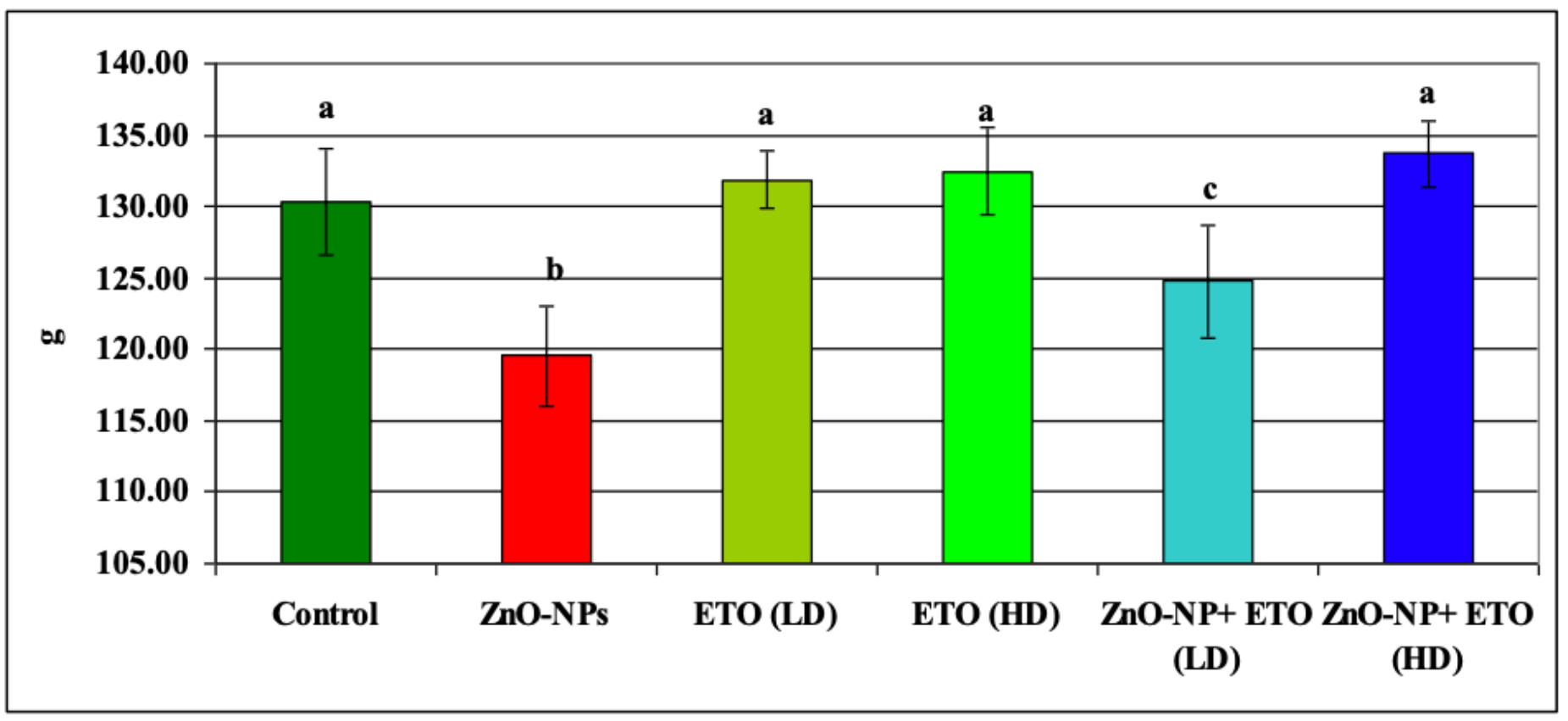

Figure 2

Effect of ETO on body weight of rats treated with ZnO-NPs 

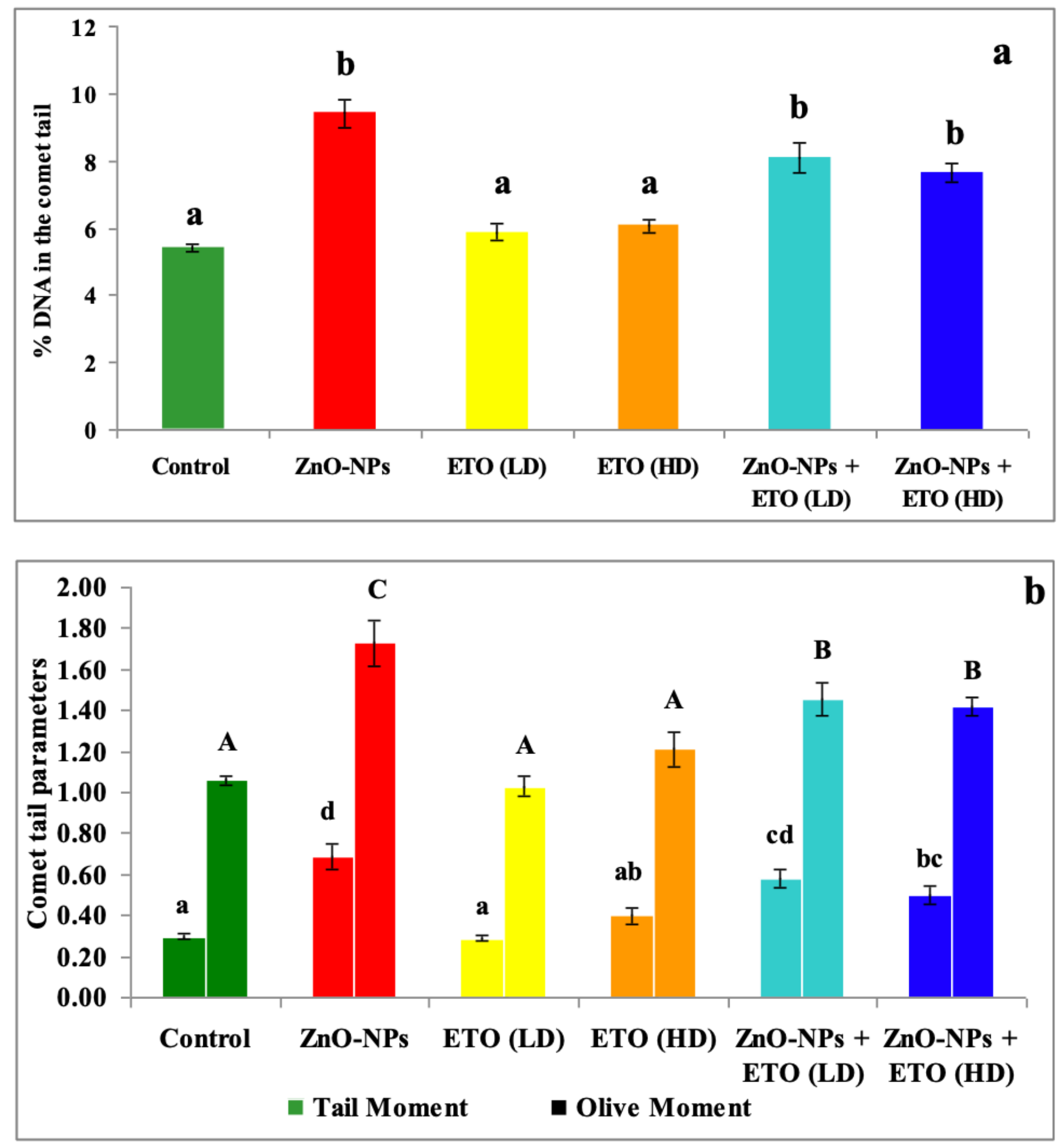

Figure 3

Effect of individual and synergistic treatment with ZnO-NPs and ETO-NPs on the \% DNA in the comet tail in bone marrow (a) and spleen (b). Total 500 cells per each group ( 5 rat/ group) were analyzed using Tritek comet score software. The means $\%$ with different superscript letters are statistically significant different $(\mathrm{P}<0.05)$ using ANOVA followed by Duncan's multiple comparisons test. Within each column, means superscripts with different letters are significantly different $(P<0.05)$ 


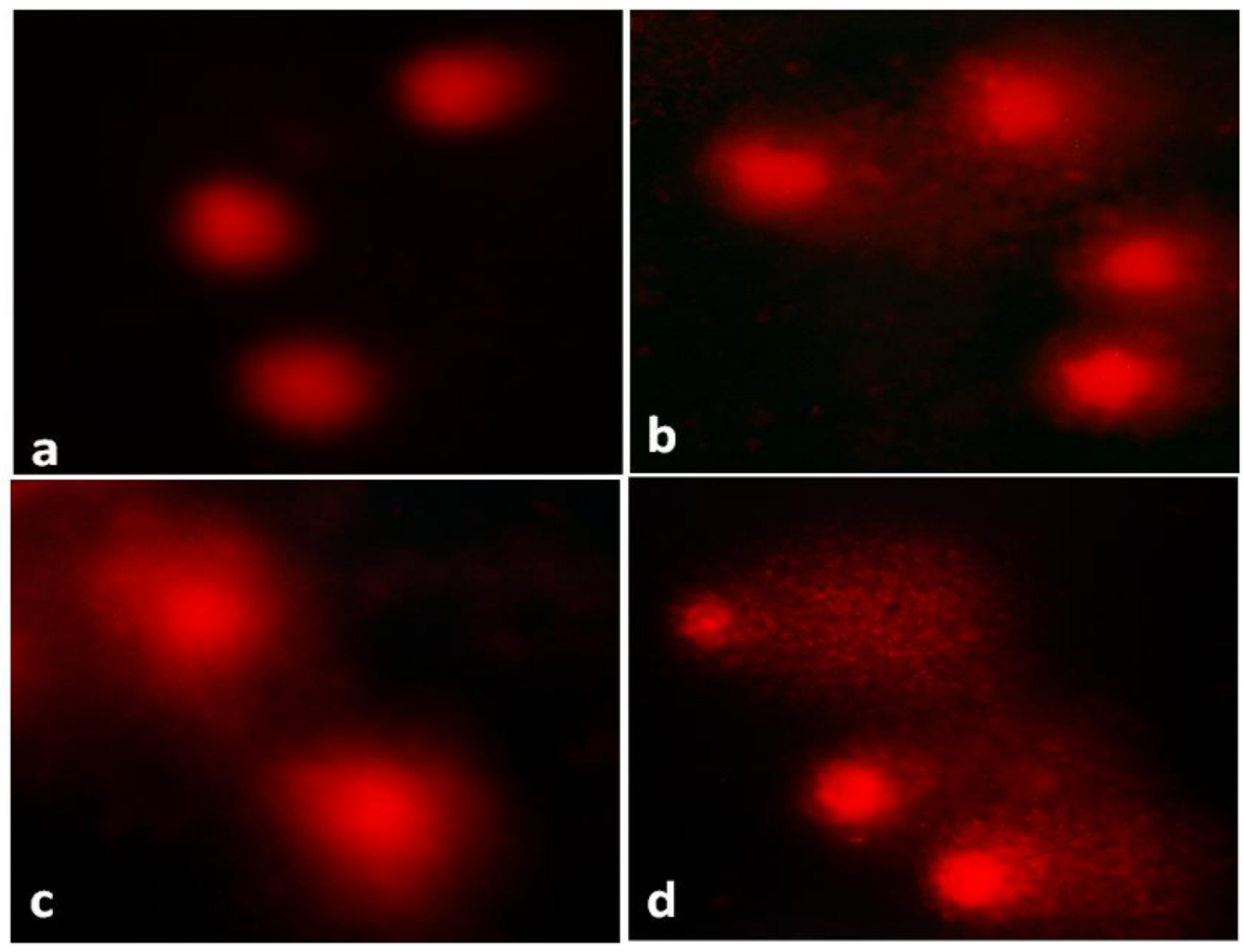

\section{Figure 4}

Fluorescent microscope photomicrographs from the cells embedded and lysed in agarose gel showing (a) intact cells; (b-d) different pattern of DNA damage using alkaline single cell electrophoresis assay (original magnification 400x).

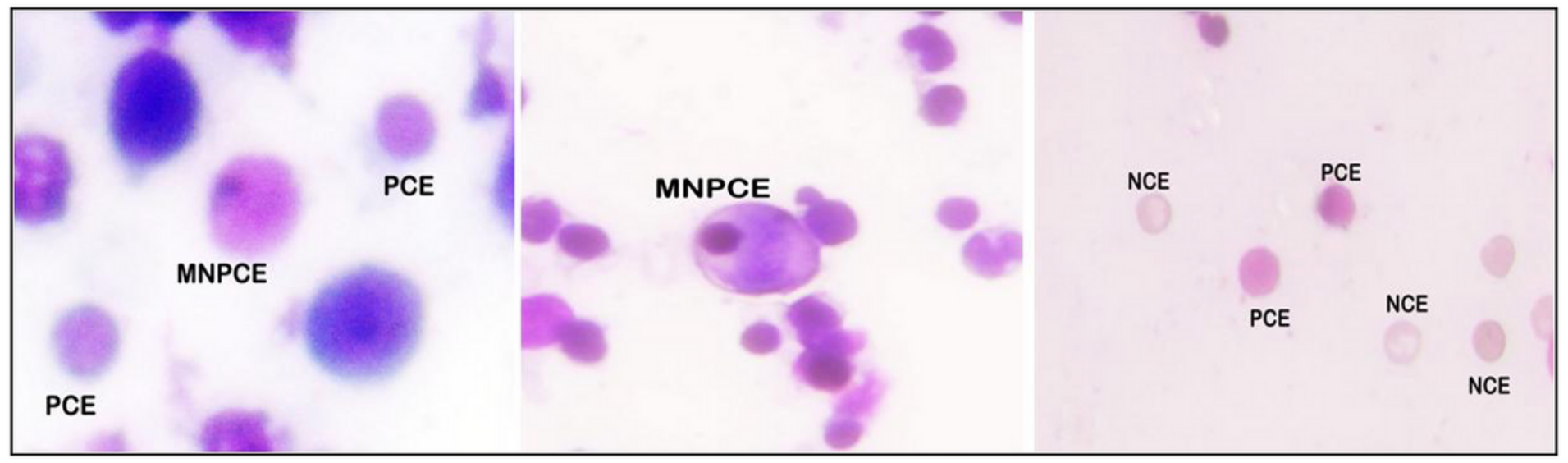




\section{Figure 5}

Light microscope photomicrographs from rat bone marrow cells showing polychromatic erythrocyte (PCE); normochromatic erythrocyte (NCE); micronucleated polychromatic erythrocyte (MNPCE) (original magnification 1000x)

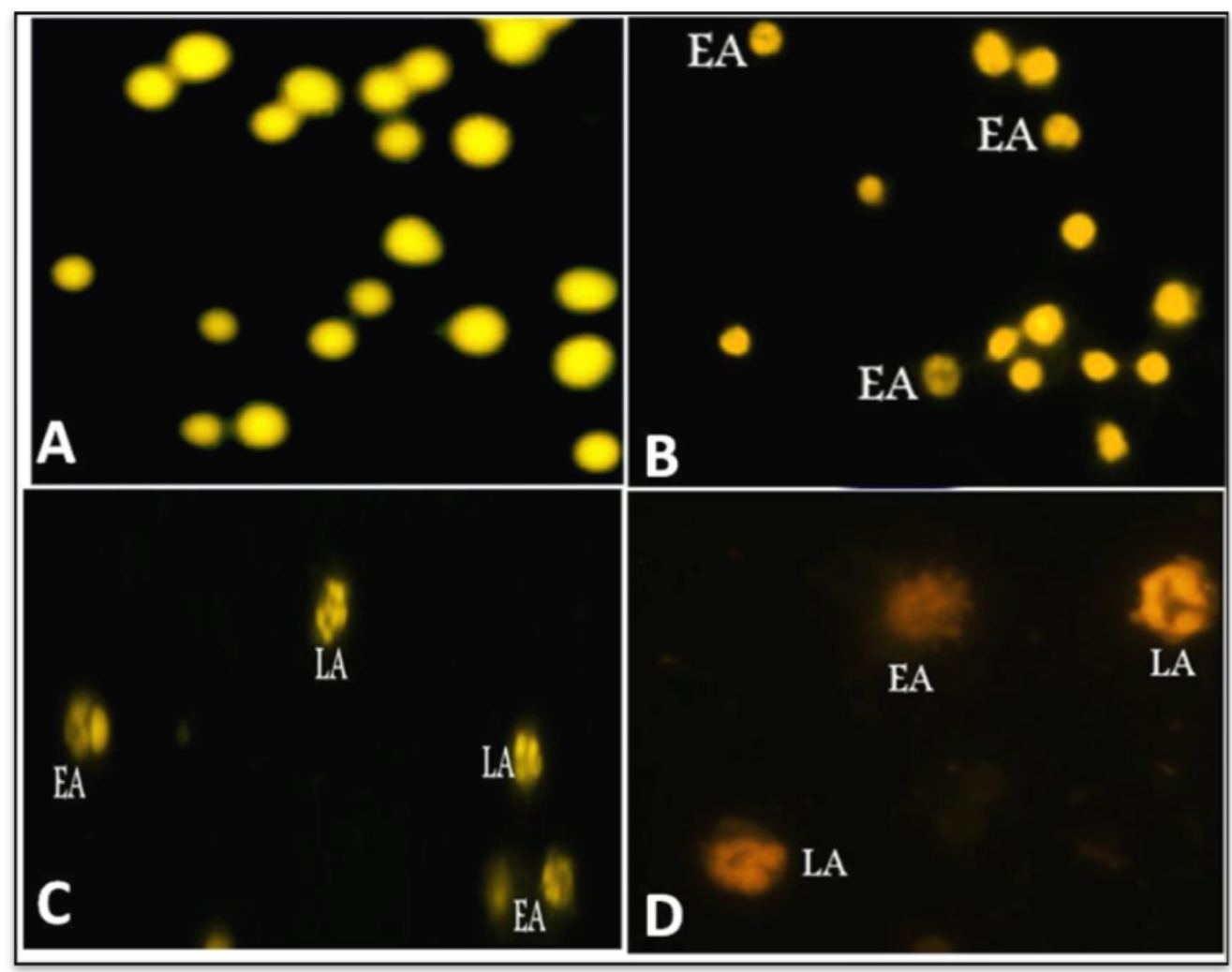

Early apoptosis (EA) and late apoptosis (LA)

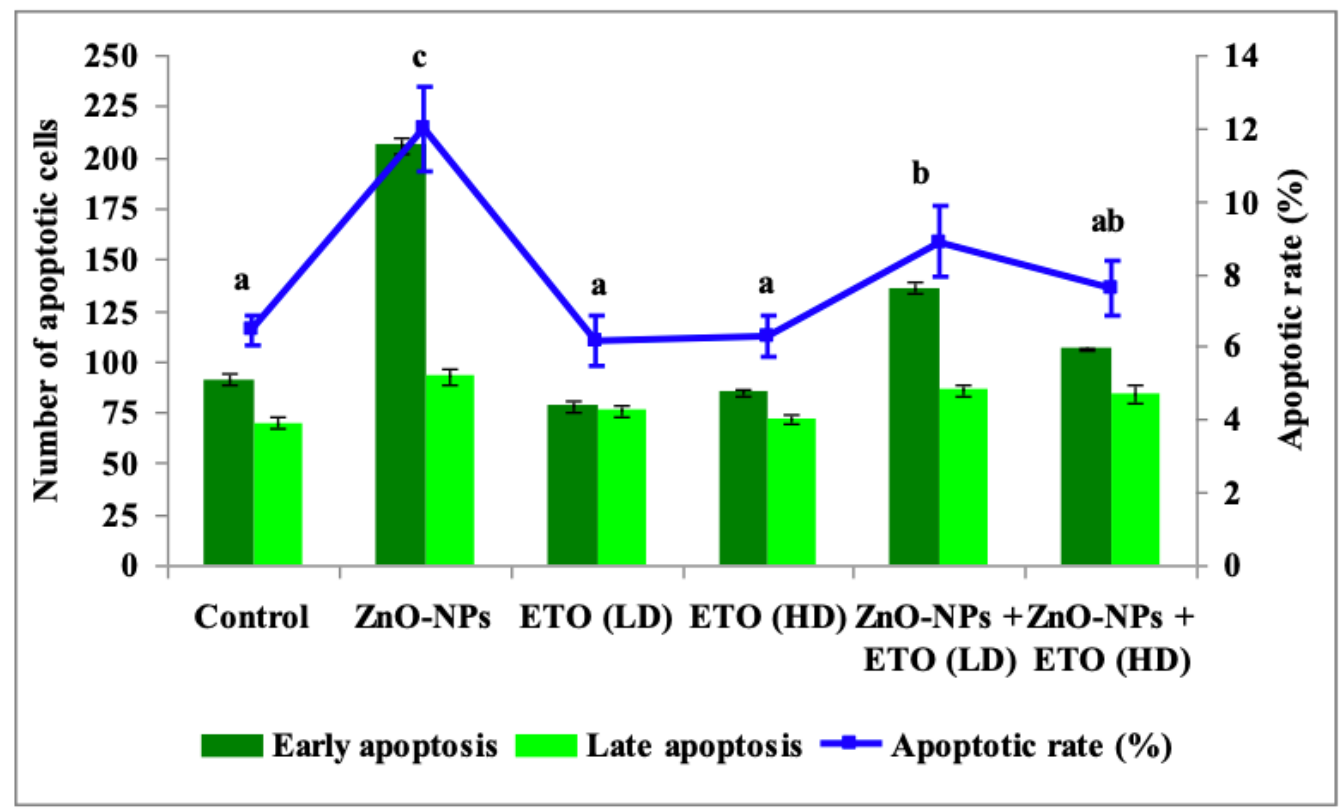

Figure 6 
Morphological changes in rat bone marrow cells stained with mixture of AO/EB showing (A) normal cells; $(B, C)$ : different stage of apoptosis including early apoptosis and late apoptosis; (D) histogram showing apoptotic rate induced after treatment with ZnO-NPs and ETO. The values with the same superscript letters are not significantly different $(P>0.05)$
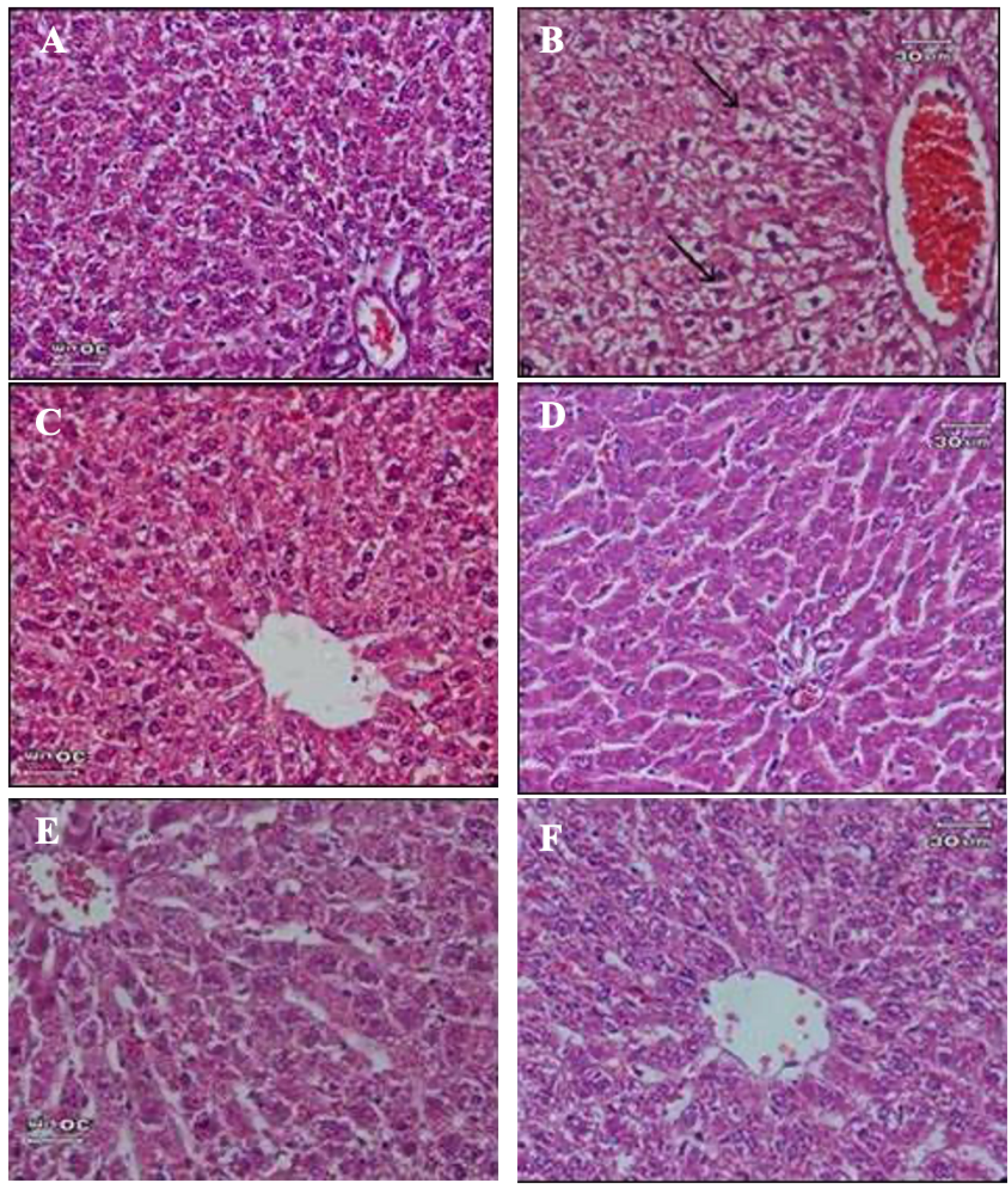

\section{Figure 7}


Photomicrographs of the liver sections of $(A)$ control rats showing normal central veins and hepatocytes; (B) rats treated with ZnO-NPs revealing hepatocytes vacuolar degeneration and pyknotic nuclei; (C, D) rats treated with low and high dose of ETO showing nearly hepatocytes and vesicle nucle and $(E, F)$ rats treated with ZnO-NPs plus the low or the high dose ETO, respectively showing improvement in hepatic cells architectures. (H \& E, X 400)
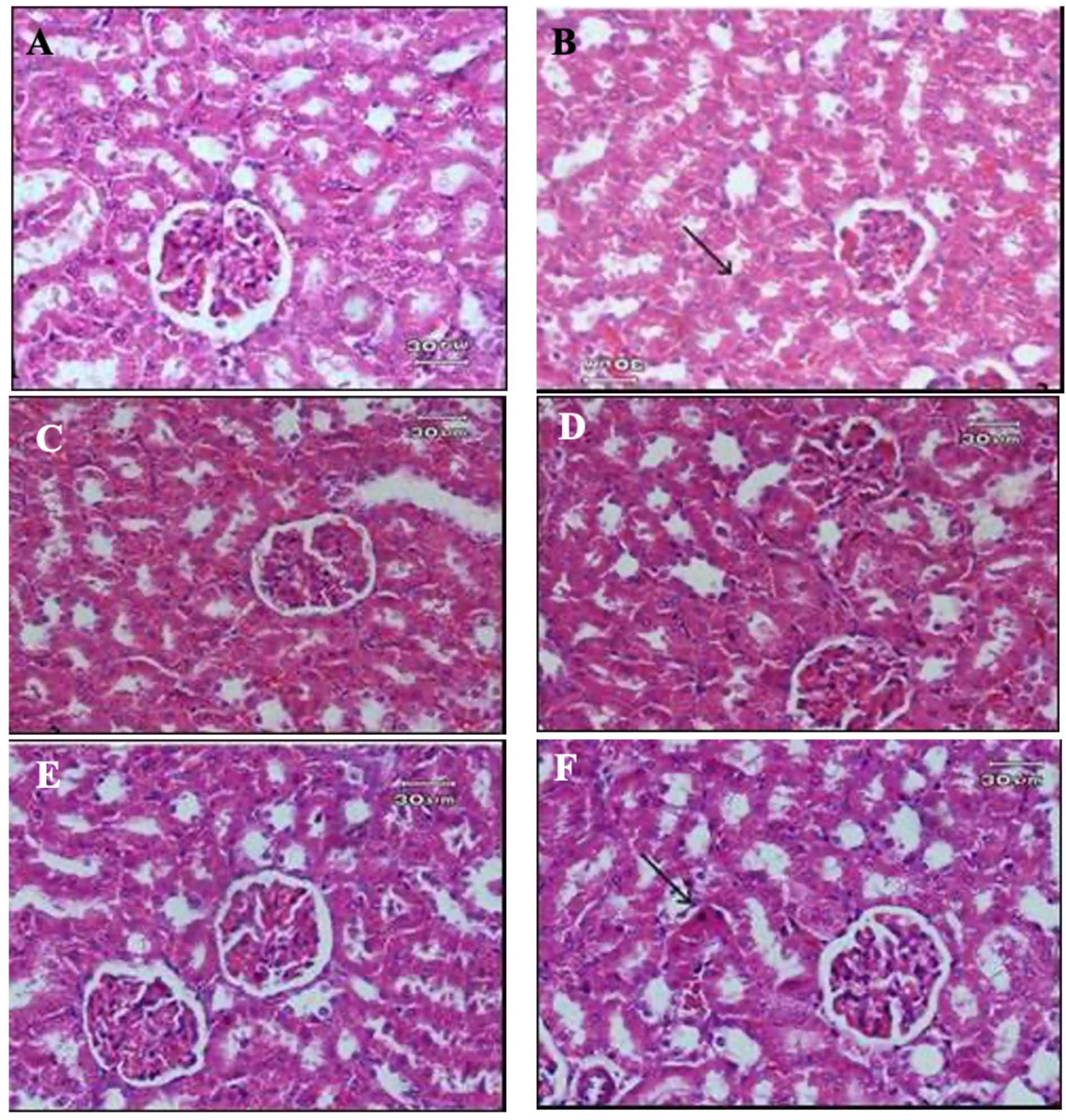

Figure 8 
Photomicrographs of the kidney sections of $(A)$ control rats showing normal parenchyma, intact renal corpuscles with normal glomerular tufts; (B) rats treated with ZnO-NPs showing swelling of the tubular lining epithelium with variable degrees of granular and single cell necrosis and nuclear pyknosis among the tubular epithelium, diminished and distorted glomeruli, atrophy of the glomerular tufts with mesangeal necrosis; (C, D) rats treated with low or high dose of ETO showing nearly normal renal tubules and glomeruli and $(E, F)$ rats treated with ZnO-NPs plus ETO showing foci of epithelial cells necrosis (arrow) $(H \& E, X 400)$ 